\title{
Stratospheric temperature trends: our evolving understanding
}

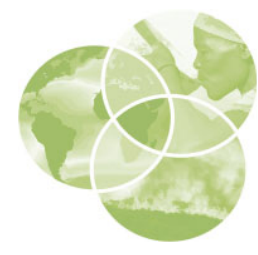

\author{
Dian J. Seidel, ${ }^{1 *}$ Nathan P. Gillett, ${ }^{2}$ John R. Lanzante, ${ }^{3}$ Keith P. Shine ${ }^{4}$ \\ and Peter W. Thorne ${ }^{5}$
}

\begin{abstract}
We review the scientific literature since the 1960s to examine the evolution of modeling tools and observations that have advanced understanding of global stratospheric temperature changes. Observations show overall cooling of the stratosphere during the period for which they are available (since the late 1950s and late 1970s from radiosondes and satellites, respectively), interrupted by episodes of warming associated with volcanic eruptions, and superimposed on variations associated with the solar cycle. There has been little global mean temperature change since about 1995 . The temporal and vertical structure of these variations are reasonably well explained by models that include changes in greenhouse gases, ozone, volcanic aerosols, and solar output, although there are significant uncertainties in the temperature observations and regarding the nature and influence of past changes in stratospheric water vapor. As a companion to a recent WIREs review of tropospheric temperature trends, this article identifies areas of commonality and contrast between the tropospheric and stratospheric trend literature. For example, the increased attention over time to radiosonde and satellite data quality has contributed to better characterization of uncertainty in observed trends both in the troposphere and in the lower stratosphere, and has highlighted the relative deficiency of attention to observations in the middle and upper stratosphere. In contrast to the relatively unchanging expectations of surface and tropospheric warming primarily induced by greenhouse gas increases, stratospheric temperature change expectations have arisen from experiments with a wider variety of model types, showing more complex trend patterns associated with a greater diversity of forcing agents. ๑ 2011 John Wiley \& Sons, Ltd. WIREs Clim Change 20112 592-616 DOI: 10.1002/wcc.125
\end{abstract}

\section{INTRODUCTION}

$\mathrm{O}$ ver the past several decades, the vertical profile of atmospheric temperature trends has become recognized as an important indicator of climate

This article is a U.S. Government work, and as such, is in the public domain in the United States of America.

*Correspondence to: dian.Seidel@noaa.gov

${ }^{1}$ NOAA Air Resources Laboratory, Silver Spring, MD, USA

${ }^{2}$ Canadian Centre for Climate Modelling and Analysis, Environment Canada, University of Victoria, Victoria, BC, Canada

${ }^{3}$ NOAA Geophysical Fluid Dynamics Laboratory, Princeton, NJ, USA

${ }^{4}$ Department of Meteorology, University of Reading, Earley Gate, Reading, UK

${ }^{5}$ Cooperative Institute for Climate and Satellites, Department of Marine, Earth, and Atmospheric Sciences, North Carolina State University and NOAA's National Climatic Data Center, Asheville, NC, USA

DOI: $10.1002 /$ wcc. 125 change, because different climate forcing mechanisms exhibit distinct vertical warming and cooling patterns. In a companion review, Thorne et al. ${ }^{1}$ surveyed the history of our understanding of temperature trends within the troposphere, the lowest $\sim 10-20 \mathrm{~km}$ of the atmosphere in which weather occurs. That review provided a chronological overview of theoretical and observational investigations of tropospheric temperature trends, in light of the ongoing controversy over whether modeled and observed trends over the past half century agree. That debate arose with the 1990 publication of results from satellite observations. $^{2}$

Thorne et al. ${ }^{1}$ concluded that models and observations currently agree within their known uncertainties. Uncertainty estimates have increased over time for two main reasons. First, there are shortcomings in global temperature observing technologies used to monitor climate, and the scope of observational 
uncertainty was not fully appreciated until different research teams endeavored to create alternative estimates of temperature change using the same basic sets of observations. Second, the intrinsic uncertainty due to climate variability, or noise, was more fully appreciated as advances in computer power spurred the development of more climate models and allowed production of multiple realizations of climate simulations, known as ensemble experiments. Advances in understanding tropospheric temperature trends have been stimulated both by the scientific controversy and by national and international scientific assessments of climate change, two of which focused solely on this issue. $^{3,4}$

This review extends the historical overview to the stratosphere, the atmospheric layer above the troposphere in the $\sim 15-50-\mathrm{km}$ altitude range. Several distinctions between tropospheric and stratospheric temperature trend research motivate separate treatment. First, although some temperature observations cover both layers, others are uniquely stratospheric. Second, until recently, different models have been used for the troposphere (where coupling to the ocean is important) and the stratosphere (because tropospheric models rarely extended deep into the stratosphere nor did they include all the physical and chemical processes necessary for simulating stratospheric climate). Third, in part because of these two differences, the scientific communities, and the resulting literatures, have been somewhat distinct. Fourth, although similar scientific uncertainties apply to both tropospheric and stratospheric temperature trends, those pertaining to the stratosphere, in contrast to the troposphere, have not entered into public policy debates, perhaps because tropospheric warming is perceived as more directly related to greenhouse-gas-induced surface climate change and associated impacts on human society and the environment.

This review follows the structure of, and makes liberal reference to, Thorne et al. ${ }^{1}$ The section Observing and Monitoring provides an overview of stratospheric temperature observations, and the section Modeling Stratospheric Temperature describes modeling approaches. The section Evolving Understanding of Temperature Trends, the heart of the review, chronologically treats model and observational research developments and international scientific assessments. The discussion is largely restricted to global average changes in the stratospheric vertical temperature profile and their relation to changes in radiative forcing factors; zonal mean trends, their seasonal variations, and their possible connection with stratospheric circulation changes are discussed briefly.
We close with a Synthesis and Current Challenges section.

\section{OBSERVING AND MONITORING STRATOSPHERIC TEMPERATURE}

Only a few observing systems offer data with long enough (i.e., multidecadal) records and the global coverage needed to evaluate stratospheric temperature trends. Balloon-borne radiosondes (with regular, quasi-global observations beginning in 1958) provide data over an irregular network of stations, and observations become less frequent with increased altitude, as seen in Figure 1. Microwave Sounding Units (MSUs), and Stratospheric Sounding Units (SSUs), which flew on U.S. National Oceanic and Atmospheric Administration (NOAA) polar-orbiting environmental satellites between 1979 and 2005, and Advanced Microwave Sounding Units (AMSUs), which continue to operate today, provide nearly globally complete data.

This section briefly reviews these observations and provides information on other systems that were useful in the past (rocketsondes), may be useful in the future (Global Navigation Satellite System or GNSS), or play an ancillary role in stratospheric temperature trend studies (stratospheric analyses, reanalyses, and lidar observations). As Thorne et al. ${ }^{1}$ discuss the radiosonde and MSU observing systems in detail, we provide only superficial coverage here. Nor do we treat the topic of building global temperature datasets, ${ }^{1}$ which involves data quality control and adjustments to remove time-varying biases that affect trend estimates, both of which involve many decisions and contribute to structural uncertainty in resulting time series. ${ }^{5}$

\section{Radiosondes and Microwave Sounding Units}

Figures 1 and 2 show the vertical coverage of radiosondes and satellite instruments, with radiosondes sampling only the lower stratosphere (LS) (up to about $30 \mathrm{~km}$ ) with detailed vertical resolution, and the MSU sampling a single deep LS layer spanning about $15-22 \mathrm{~km}$. (In addition to the LS, other MSU channels observe the troposphere and the tropopause region, which are not discussed here.) Long-term radiosonde, MSU, and, starting in 1998, AMSU records all have different time-varying biases (or inhomogeneities) with important ramifications for accurate estimation of temperature trends. ${ }^{1,4}$

Fundamentally, the focus of radiosonde and MSU observations has been in the troposphere where they are used in weather analysis and forecasting. They were not intended nor designed for monitoring 
Radiosondes OCT 2010

Frequency of reception at ECMWF

Level: $5 \mathrm{hPa}$

(a) $170^{\circ} \mathrm{W} 150^{\circ} \mathrm{W} 130^{\circ} \mathrm{W} 110^{\circ} \mathrm{W} 90^{\circ} \mathrm{W} \quad 70^{\circ} \mathrm{W} \quad 50^{\circ} \mathrm{W} \quad 30^{\circ} \mathrm{W} \quad 10^{\circ} \mathrm{W} 0^{\circ} 10^{\circ} \mathrm{E} \quad 30^{\circ} \mathrm{E} \quad 50^{\circ} \mathrm{E} \quad 70^{\circ} \mathrm{E} \quad 90^{\circ} \mathrm{E} \quad 110^{\circ} \mathrm{E} \quad 130^{\circ} \mathrm{E} \quad 150^{\circ} \mathrm{E} \quad 170^{\circ} \mathrm{E}$

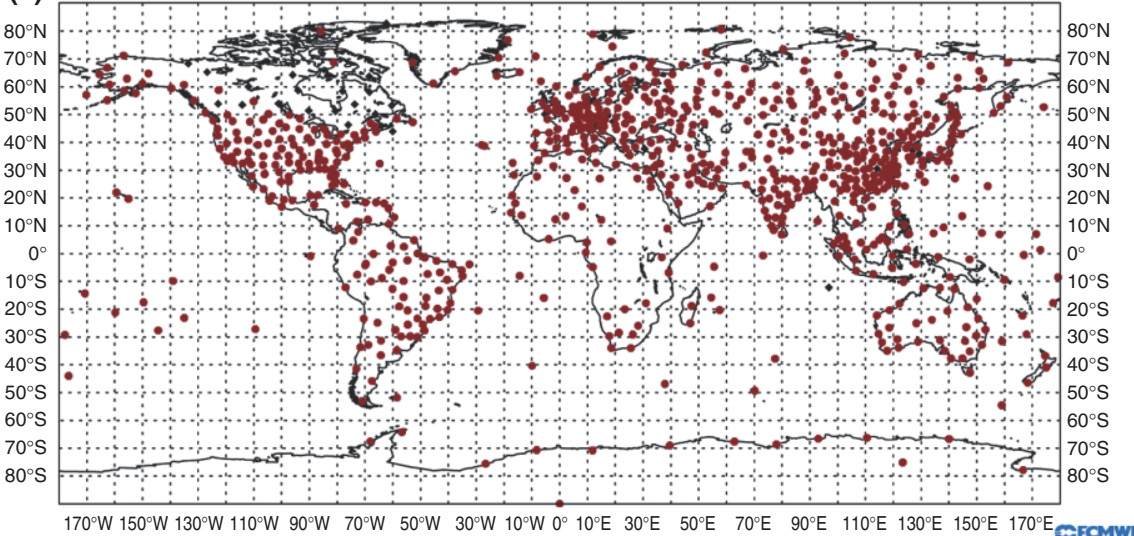

Level: $10 \mathrm{hPa}$

(b) $170^{\circ} \mathrm{W} 150^{\circ} \mathrm{W} 130^{\circ} \mathrm{W} 110^{\circ} \mathrm{W} 90^{\circ} \mathrm{W} 70^{\circ} \mathrm{W} \quad 50^{\circ} \mathrm{W} \quad 30^{\circ} \mathrm{W} 10^{\circ} \mathrm{W} 0^{\circ} 10^{\circ} \mathrm{E} 30^{\circ} \mathrm{E} \quad 50^{\circ} \mathrm{E} \quad 70^{\circ} \mathrm{E} \quad 90^{\circ} \mathrm{E} \quad 110^{\circ} \mathrm{E} 130^{\circ} \mathrm{E} \quad 150^{\circ} \mathrm{E} 170^{\circ} \mathrm{E}$

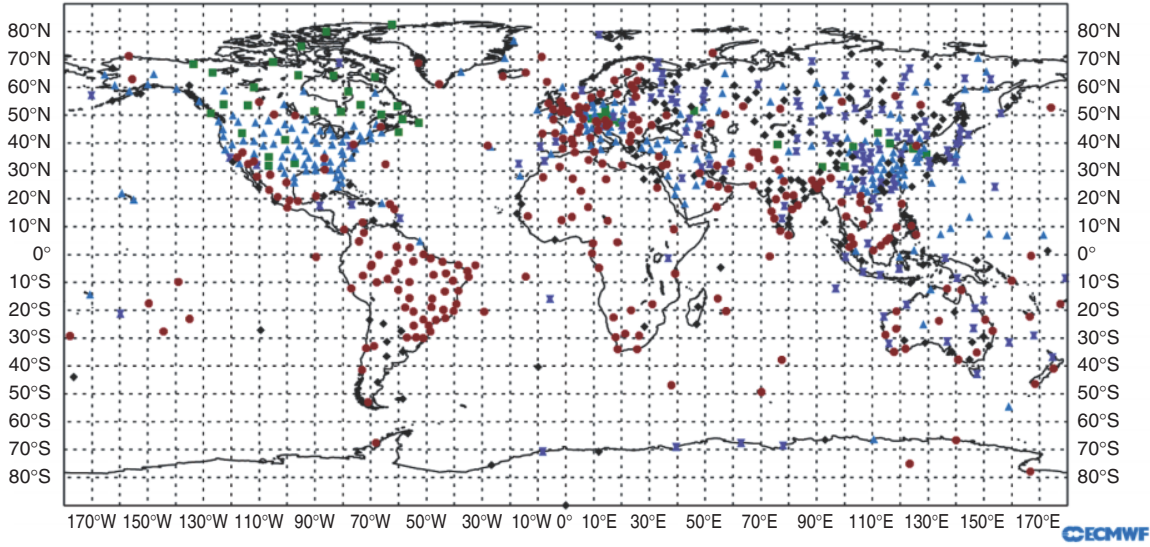

Level: $50 \mathrm{hPa}$

(c) $170^{\circ} \mathrm{W} 150^{\circ} \mathrm{W} 130^{\circ} \mathrm{W} 110^{\circ} \mathrm{W} 90^{\circ} \mathrm{W} \quad 70^{\circ} \mathrm{W} 50^{\circ} \mathrm{W} 30^{\circ} \mathrm{W} 10^{\circ} \mathrm{W} 0^{\circ} 10^{\circ} \mathrm{E} 30^{\circ} \mathrm{E} \quad 50^{\circ} \mathrm{E} \quad 70^{\circ} \mathrm{E} \quad 90^{\circ} \mathrm{E} \quad 110^{\circ} \mathrm{E} \quad 130^{\circ} \mathrm{E} \quad 150^{\circ} \mathrm{E} \quad 170^{\circ} \mathrm{E}$

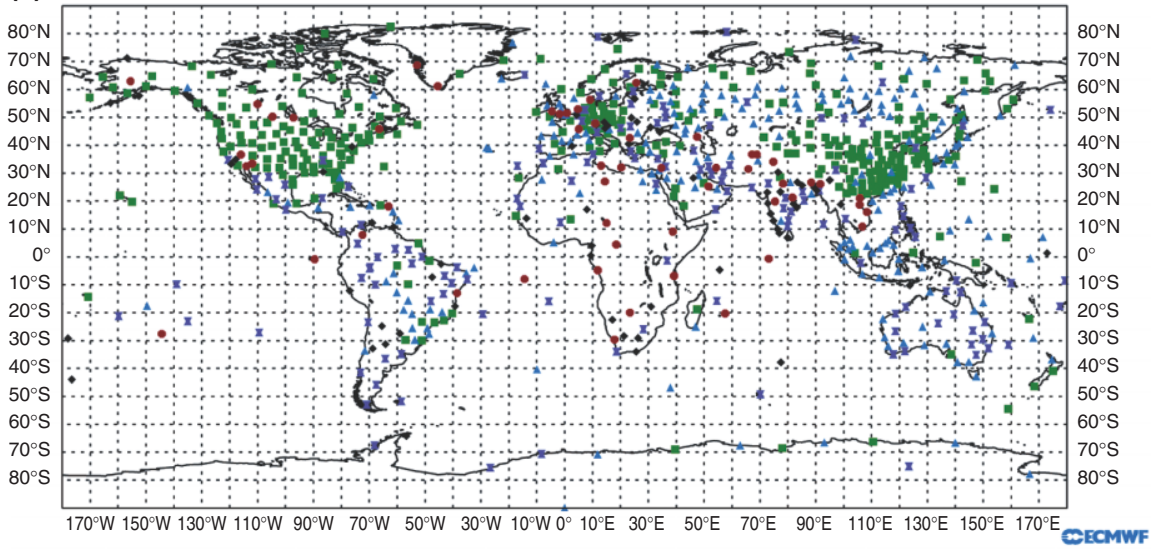

$\%$ of received data

\begin{tabular}{|c|c|c|c|c|c|c|c|}
\hline \multicolumn{8}{|c|}{$\%$ of received data } \\
\hline - & $90-100$ & $\Delta$ & $50-90$ & $\mathbf{x}$ & $25-50$ & - $1-25$ & $0-1$ \\
\hline
\end{tabular}

FIGURE 1 | Percentage of expected radiosonde temperature reports received during October 2010 by the European Centre for Medium-Range Weather Forecasts (ECMWF) for the (bottom to top) 50-, 10-, and 5-hPa levels. A comparable map showing 700-hPa reporting performance is shown by Thorne et al. ${ }^{1}$ [Figure courtesy of Antonio Garcia-Mendez (ECMWF)] 
FIG URE 2 | Vertical sampling of satellite and radiosonde observations of stratospheric temperature. Left: vertical weighting functions for satellite Microwave Sounding Unit (MSU) and Stratospheric Sounding Unit (SSU) stratospheric temperature observations as a function of pressure (left axis) and height (right axis). The dashed line at about $27 \mathrm{~km}$ (30 hPa) indicates the typical maximum height of historical global radiosondes data coverage (Figure 1). Right: schematic of atmospheric vertical structure and its latitudinal variation. (Modified from Climate Change Science Program Synthesis and Assessment Product 1.1 ${ }^{4}$ )

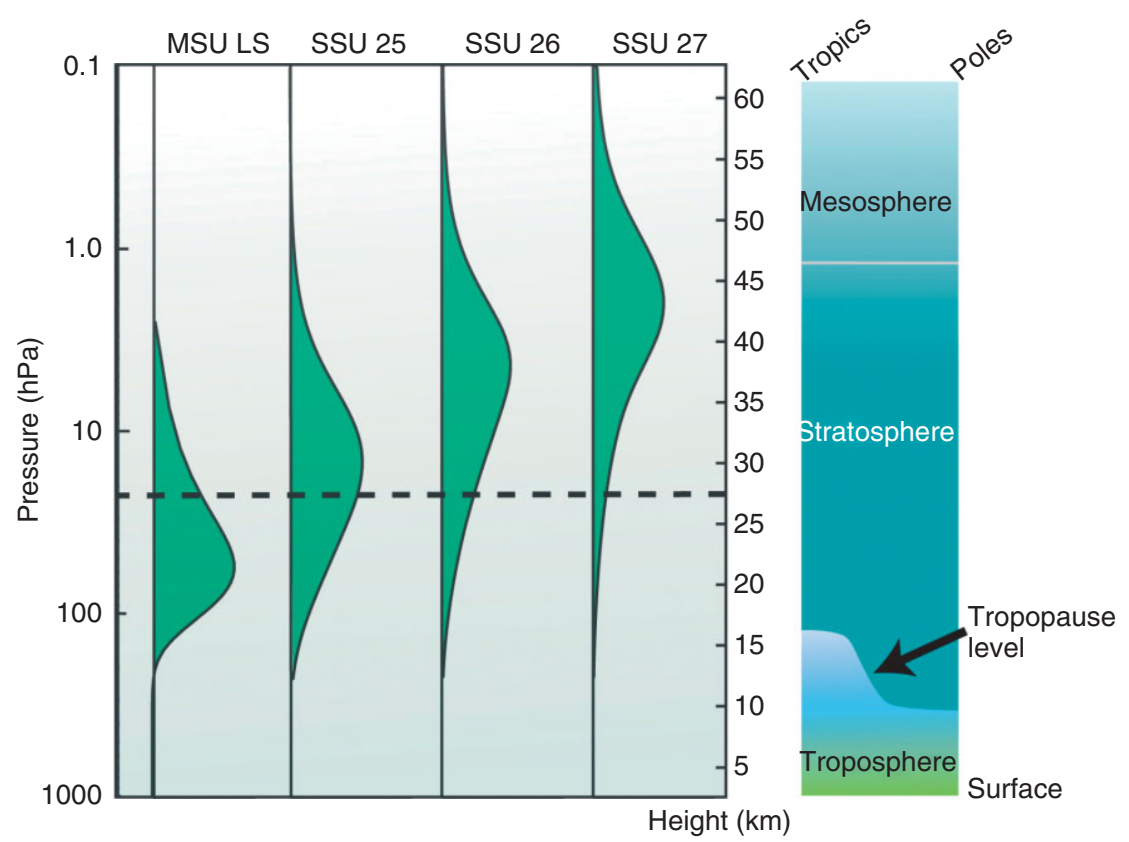

climate change. Radiosonde observations typically have larger inhomogeneities in the stratosphere than the troposphere. ${ }^{1,6,7}$ One specific stratospheric problem is that early balloons were fragile and tended to burst prematurely, particularly at low temperatures, thus undersampling higher altitudes and cold conditions. ${ }^{8}$ Contemporary radiosondes often fail to reach $50 \mathrm{hPa}$ and rarely reach $5 \mathrm{hPa}$ (Figure 1). While inhomogeneities in MSU records also have a variety of causes, ${ }^{1}$ unlike radiosondes, there is no a priori reason to expect MSU data to pose a greater challenge for determining stratospheric climate trends than tropospheric. Indeed, it has recently been shown that the MSU LS data suffer less bias for changes in satellite equatorial crossing time than the MSU tropospheric data. ${ }^{9}$ Although the radiosonde record is $\sim 20$ years longer than the MSU record, stratospheric sampling by radiosondes was more sporadic in the early years, and the geographic coverage of the radiosonde network is much less complete (Figure 1).

As an overview, Figure 3 shows the general evolution of globally averaged LS temperatures as measured by radiosondes since 1958 and MSU since 1979 and estimated from the most recently produced datasets. ${ }^{10-17}$ The data show two prominent and robust features: a long-term cooling exceeding $1 \mathrm{~K}$ and three instances of warming (of about $1 \mathrm{~K}$ in magnitude) associated with aerosols from major volcanic eruptions and lasting about 2 years. These features are larger than the uncertainty, as given by the differences between the plotted mean time series and the five different radiosonde datasets and three different MSU datasets. A third notable feature is the lack of any significant trend in globally averaged LS temperature from the mid-1990s to present.

\section{Stratospheric Sounding Units}

SSUs provide the only long-term near-global temperature data above the LS and were used in stratospheric temperature trend assessments even before MSU. ${ }^{20}$ SSUs sense infrared radiation emitted by atmospheric carbon dioxide $\left(\mathrm{CO}_{2}\right)$ in three channels ${ }^{21}$ extending from the upper troposphere to the lower mesosphere (Figure 2): channels 25 (with a peak sensitivity at $\sim 30 \mathrm{~km}), 26(\sim 40 \mathrm{~km})$, and $27(\sim 45 \mathrm{~km})$, sometimes referred to as channels 1,2 , and 3 , respectively. Synthetic channels with peak sensitivities at intermediate altitudes are constructed by combining off-nadir observations. $^{22}$

Like MSU, the SSU was designed for weather forecasting rather than climate monitoring, and the analysis of SSU data shares many of the problems associated with MSU. Data are from a series of different satellites, with differing and drifting equatorial crossing times, frequently with little overlap between satellites. The period from 1978 to 2006 can be roughly characterized as seven segments when data from either a single or two different satellites carrying SSUs were available (see Ref 1, figure 5).

The SSU data require correction for three additional problems. First, the satellite carries a cell of $\mathrm{CO}_{2}$, a vital part of the pressure modulator technique used to observe stratospheric emission, but the cells leak (causing an apparent but spurious increase in observed temperature), and their $\mathrm{CO}_{2}$ 


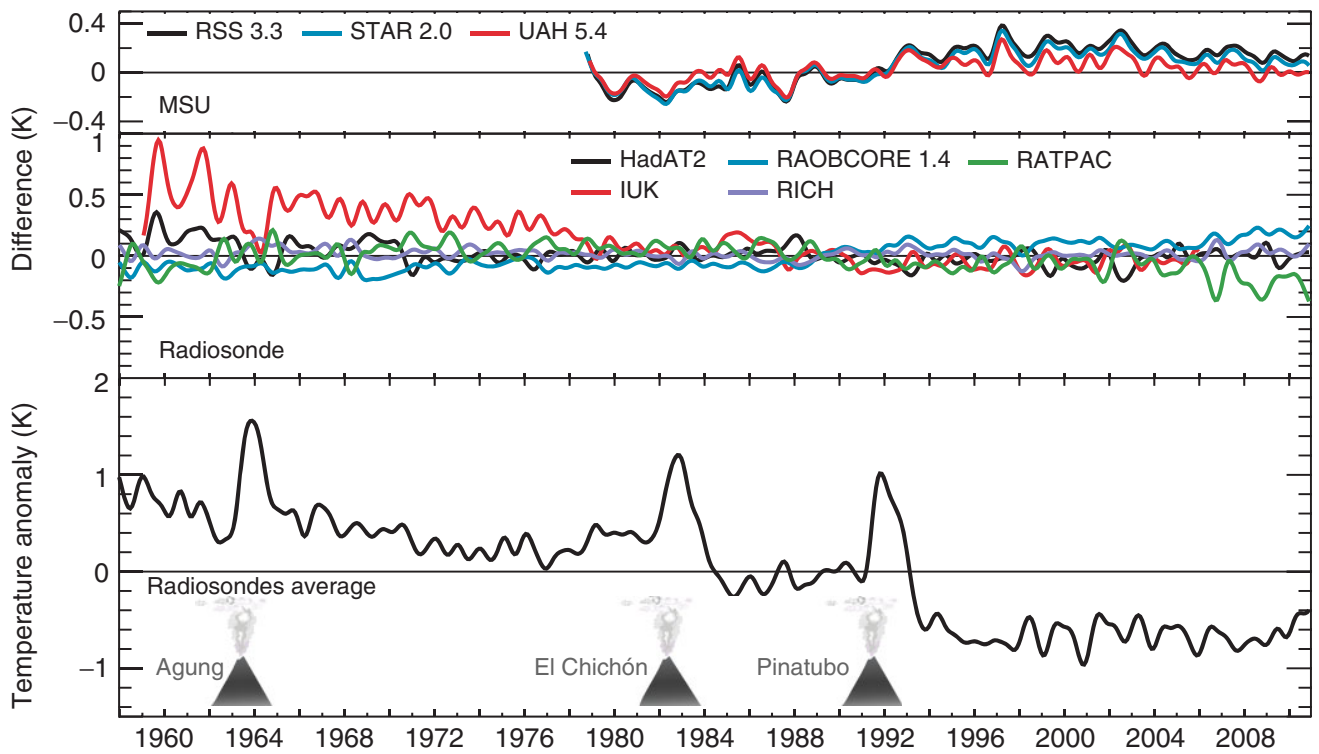

FIGURE 3 | Smoothed global mean lower stratospheric temperature anomalies for 1958-2010 based on five radiosonde [Hadley Centre Atmospheric Temperatures (HadAT), ${ }^{10}$ Radiosonde Atmospheric Temperature Products for Assessing Climate (RATPAC), ${ }^{11}$ Iterative Universal Kriging (IUK), ${ }^{12}$ RAdiosonde OBservation COrrection using REanalyses (RAOBCORE), ${ }^{13}$ and Radiosonde Innovation Composite Homogenization (RICH) ${ }^{14}$ ] and three MSU [Remote Sensing Systems (RSS), ${ }^{15}$ University of Alabama in Huntsville (UAH), ${ }^{16}$ and NOAA Center for Satellite Applications and Research $(\mathrm{STAR})^{17,18}$ ] datasets. Radiosonde data at different pressure levels have been averaged to correspond with the Microwave Sounding Unit (MSU) weighting function (Figure 2). The bottom trace is the mean of four of the five radiosonde datasets (excluding IUK, which does not extend beyond 2005). Anomalies are differences from 1979 to 1998 monthly mean values. Symbols indicate major volcanic eruptions with aerosols penetrating into the stratosphere in 1963 (Agung), 1982 (El Chichón), and 1991 (Pinatubo). Differences between individual datasets and the radiosonde mean are shown separately for the MSU (top) and radiosonde (middle) datasets. (Updated and modified from State of the Climate in $2008^{19}$ and courtesy of Carl Mears, Remote Sensing Systems, and Katharine Willett, UK Met Office Hadley Centre)

content varies among SSU instruments. ${ }^{23}$ Second, at the higher altitudes sensed by the SSU, the large diurnal and semidiurnal tides (due to absorption of solar radiation) require corrections that vary as equatorial crossing times change. ${ }^{20,24}$ Finally, long-term temperature trends derived from SSU need adjustment for increasing atmospheric $\mathrm{CO}_{2} .{ }^{25}$ Because these corrections are particularly difficult for the synthetic channels, we do not treat those data here.

As with MSU, SSU has been replaced by AMSU, with five channels covering the domain previously observed by the three SSU channels. ${ }^{23}$ Despite recent use of AMSU data to infer stratospheric temperature trends $^{26}$ and ongoing efforts to produce a coherent combined SSU/AMSU temperature record, such work is not yet mature enough to assess here.

Until recently, the only analysis of SSU data available in the literature was the work of Nash et al. ${ }^{20,27,28}$ recently updated by Randel et al. ${ }^{21}$ Liu and Weng ${ }^{29}$ have now produced an alternative analysis for channels 25 and 26, which allows at least limited evaluation of structural uncertainty in derived trends associated with methodological choices. Figure 4 shows global temperature anomaly time series presented in these two papers and their differences for the two channels in common. In contrast to the MSU LS data (Figure 3), there are fewer independent analyses of SSU data and no radiosonde observations for comparison (except for SSU channel 25, which senses a layer similar to MSU LS; Figure 2). We discuss the long-term behavior of SSU time series in the section on Reinvigorated Analyses of Stratospheric Temperature Observations.

\section{Other Observing Systems and Analyses}

Early studies of stratospheric temperature trends incorporated rocketsonde observations [see World Meteorological Organization $(\mathrm{WMO})^{30}$ and references therein], mostly from Japan, the USA, and the former USSR, but the network is now essentially defunct. During its mid-1960s heyday, the US program launched rocketsondes at 30 sites several times per week, ${ }^{30}$ and for a time rocketsondes were the only source of observations in the 30-70$\mathrm{km}$ region. ${ }^{31,32}$ But rocketsondes never provided global stratospheric observations; only 12 sites had coherent records spanning roughly the mid-1960s to mid-1990s. ${ }^{33}$ Moreover, differing sensor types and changes in the corrections applied, and the lack of 


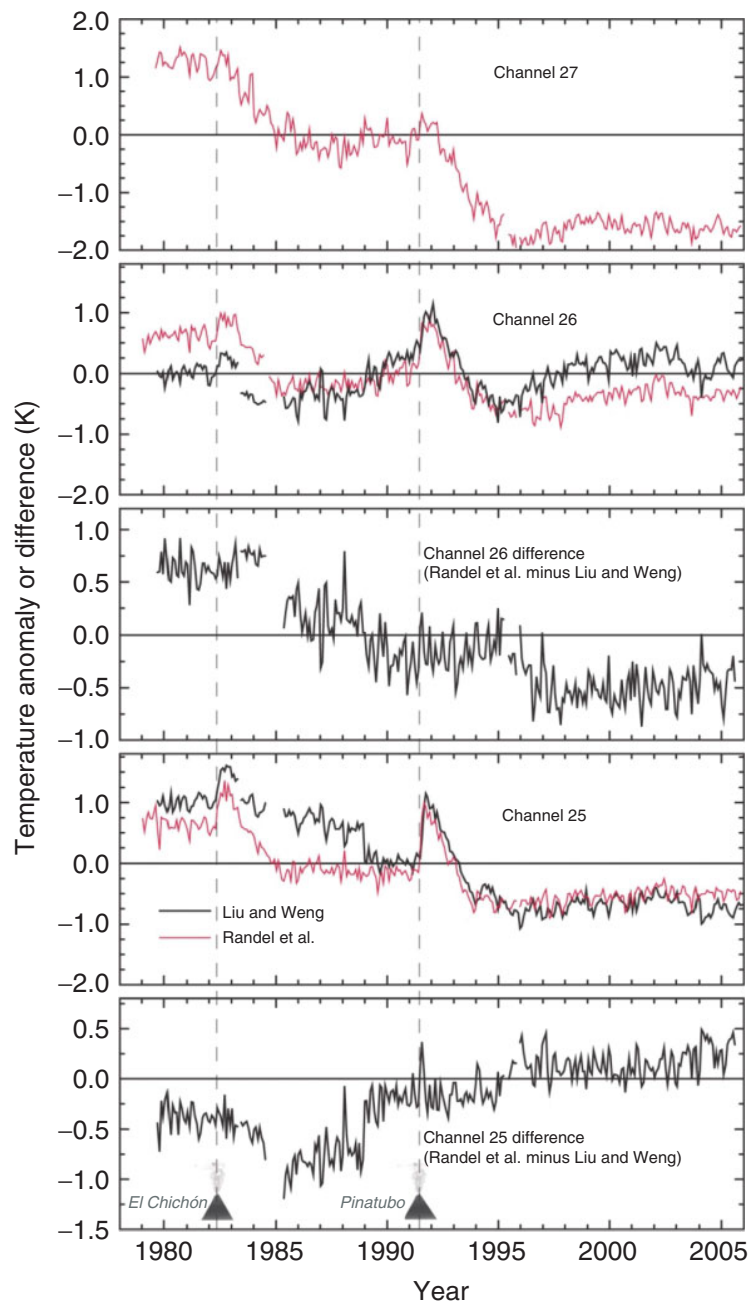

FIG URE 4 | Global temperature anomaly time series from Stratospheric Sounding Unit (SSU) data from the three SSU channels, as analyzed by Randel et al. ${ }^{21}$ and, for channels 25 and 26, as analyzed by Liu and Weng, ${ }^{29}$ and differences between them for channels 25 and 26. Symbols indicate major volcanic eruptions in 1982 (El Chichón) and 1991 (Pinatubo).

independent observations for comparison, pose considerable challenges to their use in trend studies.

Ground-based lidar measurements have largely superseded rocketsondes in the $30-75-\mathrm{km}$ region. ${ }^{34}$ Lidars emit laser pulses and measure their backscatter to derive atmospheric density profiles. Currently, only three stations have at least two decades of data, which are not sufficient to provide a global view of temperature trends. ${ }^{21,35}$ Even local trends are difficult to interpret, because of the irregular observing schedules (only in clear conditions at night) and because trends at two nearby sites in Europe differ significantly, perhaps due to temporal sampling differences. ${ }^{21}$ Nevertheless, lidars can provide some corroborative evidence for the trends estimated from satellite observations.
GNSS (or Global Positioning System, GPS) radio occultation $(\mathrm{RO})$ measurements are an emerging climate monitoring technology, particularly applicable to stratospheric temperature studies. Navigational signals from GNSS satellites are received by lowEarth-orbiting RO satellites after being refracted by the intervening atmosphere. Associated delays can be converted to profiles of geophysical parameters (refractivity, temperature, and humidity). ${ }^{36}$

GNSS RO data are available globally and cover the entire atmospheric column with high vertical resolution $(<1 \mathrm{~km})$. However, broad $(\sim 200 \mathrm{~km})$ horizontal weighting functions, and horizontal variability along the path, can introduce retrieval errors. Occultation measurements are not made on a regular schedule but occur when GNSS and RO satellite orbital geometries are suitable. Moreover, because obtaining temperature profiles requires additional processing, temperature data are not directly traceable to a standard and methodological choices introduce structural uncertainty. ${ }^{37-40}$ Because RO records from a series of different measurement campaigns are short [CHAllenging Mini-satellite Payload (CHAMP): 2001-2008, Constellation Observing System for Meteorology, Ionosphere \& Climate (COSMIC): 2006-present, GNSS Receiver for Atmospheric Sounding (GRAS): 2008-present, Global Positioning System/Meteorology (GPS/MET): only during 1995-1997 and sporadic], their value for trend monitoring is currently limited, although short-term trends have been estimated. ${ }^{41}$

Atmospheric analyses and reanalyses are potential sources of stratospheric temperature trend information. Analyses are maps of temperature data, prepared either manually or through assimilation into a model, that incorporate a variety of observation types. In stratospheric climate research (more so than for the troposphere), analyses have played an important role, with research teams at the NOAA National Weather Service ${ }^{42}$ and at the Free University of Berlin ${ }^{43,44}$ monitoring stratospheric conditions on a routine basis for several decades. Although important for identifying short-term stratospheric variations, such as sudden stratospheric warmings and the quasibiennial oscillation $(\mathrm{QBO})$, analyses are problematic for trend studies because they do not address potential data inhomogeneities.

Reanalyses are globally complete datasets resulting from assimilation of many types of observations into a single model to create a physically consistent rendering of the atmosphere. Owing to changes over time in the observing system, reanalyses have generally contained time-varying biases, making them ill-suited for temperature trend analyses in many regions, ${ }^{4,45-51}$ 
particularly in the stratosphere, ${ }^{21,52,53}$ although the newest $\mathrm{t}^{23}$ and future reanalyses may prove more applicable in this area. ${ }^{45,54}$

\section{MODELING STRATOSPHERIC TEMPERATURE}

Numerical models that simulate climate processes are necessary to identify causes of temperature trends and project future changes. In contrast with modeling studies of tropospheric temperature trends, where general circulation models (GCMs) quickly superseded one-dimensional (1-D) radiative convective models (RCMs) and have dominated the literature for decades, ${ }^{1}$ a wide diversity of model types, summarized in Table 1 , has been used to calculate stratospheric temperature change.

1-D (vertical) RCMs were widely used in early work, ${ }^{55-57}$ where changes in constituents such as $\mathrm{CO}_{2}$ and ozone were imposed on the model. In the 1970s, 1-D models, with specified surface

TABLE 1 Comparison of Climate Model Types Used in Studies of Stratospheric Temperature Trends from the 1970s to Present, in Approximate Chronological Order of Introduction, with Earlier Types at the Top

\begin{tabular}{|c|c|c|}
\hline Model Type & Geometry & Processes \\
\hline $\begin{array}{l}\text { One-dimensional } \\
\text { models }\end{array}$ & $1-D$ & $\begin{array}{l}\text { Radiative transfer } \\
\text { Vertical mixing (sometimes } \\
\text { including tropospheric } \\
\text { convection) } \\
\text { Chemical processes } \\
\text { (sometimes) }\end{array}$ \\
\hline $\begin{array}{l}\text { General circulation } \\
\text { models }\end{array}$ & $3-D$ & $\begin{array}{l}\text { Radiative transfer } \\
\text { Vertical mixing (convection) } \\
\text { Atmospheric dynamics }\end{array}$ \\
\hline 2-D models & $2-D$ & $\begin{array}{l}\text { Radiative transfer } \\
\text { Vertical mixing (sometimes } \\
\text { including tropospheric } \\
\text { convection) } \\
\text { Atmospheric dynamics } \\
\text { Chemical processes }\end{array}$ \\
\hline $\begin{array}{l}\text { Fixed dynamical } \\
\text { heating models }\end{array}$ & Normally 2-D & Radiative transfer \\
\hline $\begin{array}{l}\text { Chemistry-climate } \\
\text { models }\end{array}$ & $3-D$ & $\begin{array}{l}\text { Radiative transfer } \\
\text { Vertical mixing (convection) } \\
\text { Atmospheric dynamics } \\
\text { Chemical processes }\end{array}$ \\
\hline
\end{tabular}

Geometry indicates the number of spatial dimensions represented. Physical processes include those represented explicitly or in parameterized form in most models of the type in question. and tropospheric temperatures, were developed that included representations of stratospheric chemistry, thereby allowing representation of feedbacks between temperature change (e.g., due to $\mathrm{CO}_{2}$ changes) and ozone concentrations. ${ }^{58-60}$ Because of the strong latitudinal variations in predicted changes in ozone, two-dimensional (2-D, latitude-height) models, which included the interaction between simplified dynamics, radiation, and chemistry, ${ }^{61,62}$ played an important role in the development of understanding of stratospheric temperature change and are still in occasional use today.

Fixed dynamical heating (FDH) models were introduced in the late 1970s. ${ }^{63,64}$ These normally 2-D (latitude-height) models assume that following a change in constituent concentrations (such as ozone or $\mathrm{CO}_{2}$ ), radiative processes drive temperature change, while heating due to convergence of dynamical heat fluxes remains unchanged. The FDH assumption gives reasonable temperature change estimates, at least in low to mid latitudes, compared to GCM calculations, ${ }^{64-66}$ at much reduced computational cost. They continue to be used today, partly because of the importance of stratospheric temperature change for the computation of radiative forcing for some climate change mechanisms (most notably changes in stratospheric ozone), and partly to diagnose causes of temperature changes in GCM experiments.

GCMs, the main modern tool for simulating stratospheric temperature change, are threedimensional (3-D) representations of the atmosphere, sometimes coupled to a 3-D ocean model, and possibly other climate system components such as sea ice and land surfaces. GCM simulations of tropospheric climate change ${ }^{67}$ typically do not contain sophisticated representations of atmospheric chemistry, and changes in stratospheric ozone have generally been imposed rather than fully modeled. Another historical shortcoming for stratospheric temperature studies is limited vertical extent and poor vertical resolution in the stratosphere, although many contemporary models are less restricted.

Coupled chemistry-climate models (CCMs) are atmospheric GCMs that represent stratospheric chemistry, particularly the processes most important for stratospheric ozone, ${ }^{68-70}$ including transport of ozone-depleting substances (ODSs) into the stratosphere and gas phase and heterogeneous chemical processes involving ODSs, ozone, and other constituents. CCMs represent the troposphere, although with highly simplified tropospheric chemistry. They do not usually include ocean processes; sea surface temperatures are generally specified from observations or other models. They generally have relatively high 
vertical resolution in the stratosphere and simulate the main dynamical, radiative, and chemical processes that drive stratospheric temperature change. However, large differences in projected ozone changes ${ }^{69,71}$ introduce additional uncertainty into simulated stratospheric temperature changes compared with model simulations that impose observed ozone changes.

\section{EVOLVING UNDERSTANDING OF TEMPERATURE TRENDS}

This section chronologically reviews the evolution of understanding of stratospheric temperature trends since the late 1960s. We also discuss short-term temperature variations [due to the El Niño-Southern Oscillation (ENSO), the QBO, major volcanic eruptions, and solar variations]. Temperature trends at the tropopause, the interface between the troposphere and stratosphere, ${ }^{72-74}$ are outside the scope of this review.
A detailed review of the evolution of factors that force stratospheric temperature change (Figure 5) is also outside our scope, but a brief description is necessary to provide the context for understanding modeled and observed temperature trends.

- Carbon dioxide and other long-lived greenhouse gases (LLGHGs) — generally well-observed increase since preindustrial times. ${ }^{75} \quad \mathrm{CO}_{2}$ induced cooling also influences stratospheric ozone; the associated impact on temperature is now sometimes included when temperature trends are attributed to changes in $\mathrm{CO}_{2}$.

- ODSs-well-observed increase from mid-20th century until the implementation of the Montreal Protocol on Substances that Deplete the Ozone Layer in the late 1980s, with changes in the mix of substances over time and a slow decrease
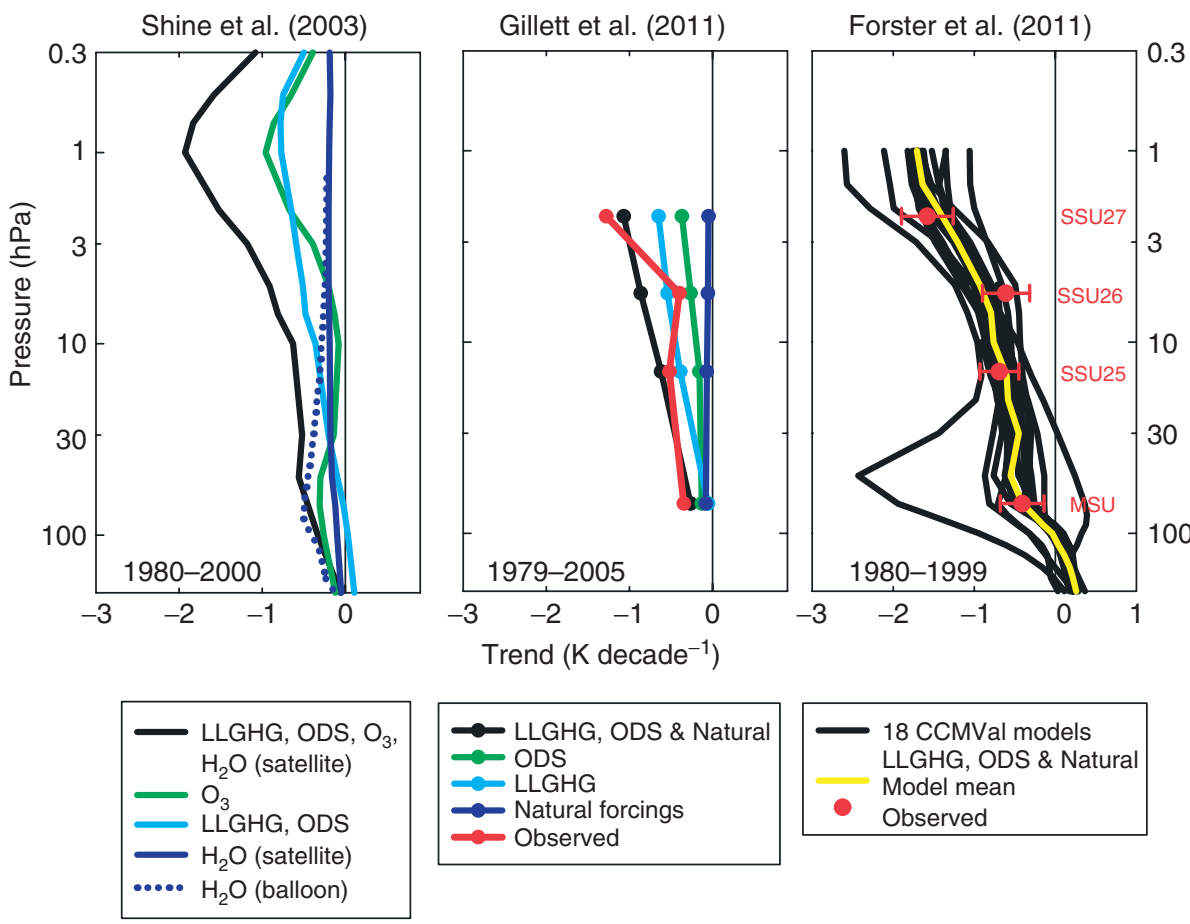

FIG URE 5 | Modeled and observed global stratospheric temperature trend profiles. Left: simulated global mean temperature trends for approximately 1980-2000, based on an average of several models, due to changes in long-lived greenhouse gases (LLGHGs) (including $\mathrm{CO}_{2}, \mathrm{CH}_{4}$, and $\mathrm{N}_{2} \mathrm{O}$ ) and various ozone-depleting substances (ODSs), changes in stratospheric ozone, and two different estimates (from balloon and satellite observations) of changes in stratospheric water vapor (Modified from Shine et al. ${ }^{85}$ ). Middle: simulated and observed 1979-2005 global mean temperature trends. Simulations are multimodel means, from seven chemistry-climate models (CCMs), of trends due to changes in LLGHGs (including $\mathrm{CO}_{2}, \mathrm{CH}_{4}, \mathrm{~N}_{2} \mathrm{O}$, and associated changes in ozone and water vapor), ODSs [including chlorofluorocarbons (CFCs), hydrochlorofluorocarbons (HCFCs), and Halons and associated simulated changes in ozone, etc.], and natural forcings (volcanic aerosols and solar changes). Observations are from Stratospheric Sounding Unit (SSU) and Advanced Microwave Sounding Unit (AMSU)/Microwave Sounding Unit (MSU). Symbols are plotted at representative pressures for each satellite channel, and model trends, vertically weighted to correspond with these channels, are plotted at the same pressures (Modified from Gillett et al. $\left.{ }^{86}\right)$. Right: simulated and observed $1980-1999$ near-global $\left(70^{\circ} \mathrm{N}-70^{\circ} \mathrm{S}\right)$ temperature trends. Simulations are by 18 CCMs; individual and multimodel mean results are shown. Observations are from MSU and SSU. Error bars on observed trends are $95 \%$ confidence intervals. (Modified from CCMVal Report ${ }^{69}$ and Forster et al. ${ }^{87}$ ) 
in many of them in recent years. ${ }^{52}$ Some ODSs [notably chlorofluorocarbons (CFCs)] could also be classified as LLGHGs but are often classified separately, as their dominant global mean effect on stratospheric temperature is associated with ozone depletion.

- Ozone-well-observed and marked springtime decrease in the Antarctic stratosphere that had become established by the early 1980s and continues to present; more modest global stratospheric decreases whose latitude and height dependence are known with less confidence. Increases in tropospheric ozone in most locations..$^{52,76}$

- Stratospheric water vapor-evidence of increasing concentrations during the latter decades of the 20th century based on balloon-borne and satellite observations, but these are either of limited spatial extent or limited duration; better documented, abrupt decrease in about $2001^{52,77-79}$ and increase later in the decade. ${ }^{80,81}$

- Solar radiation-direct observations of incoming solar radiation from satellites began in late 1970s showing an 11-year cycle and other variability. ${ }^{75}$ Significant uncertainty in the wavelength dependence of that variability, ${ }^{82-84}$ with potential impact on temperature.

- Volcanic aerosols-episodic injections (Figure 3) into the stratosphere resulting in sulfate particles which have an e-folding lifetime of 1-2 years. No major eruptions since Mt. Pinatubo in $1991 .{ }^{75}$

- Sea surface temperature-used to force CCMs; main variations are associated with ENSO and a multidecadal warming trend.

Because some of these show (coincidental or physically related) correlations (such as solar variations and volcanic aerosols, or LLGHGs and sea surface temperatures), isolating their effects is challenging.

To provide context, Figure 5 shows model-based representations of the effects of different forcings on the vertical temperature profile for a 20 -year period ( 1980-2000), from three 21st century studies, ${ }^{85-87}$ two of which resulted from the Chemistry-Climate Model Validation Activity (CCMVal) involving 18 contemporary models. ${ }^{69}$ The CCMVal simulations (Figure 5, right) show stratospheric cooling from about 100 to $1 \mathrm{hPa}$, and warming of the upper troposphere.

The net effect of LLGHG increases is cooling that increases with height. Likewise, ODSs (through their effect on ozone) cool the stratosphere, with cooling increasing with height to the stratopause (the top of the stratosphere, at $\sim 50 \mathrm{~km}, 1 \mathrm{hPa}$ ). Models forced by observed ozone trends show stratospheric cooling with a more complex vertical profile than in the LLGHG and ODS cases, and they indicate that a potentially large cooling effect would result from increases in stratospheric water vapor, but with large uncertainty associated with the uncertainty in those changes $^{85}$ (Figure 5, left).

\section{Early Model and Observational Studies (1960s and 1970s)}

The earliest modeling studies discussing stratospheric temperature trends focused on anthropogenic increases in atmospheric $\mathrm{CO}_{2}$ modifying temperature throughout the atmosphere. The seminal RCM study by Manabe and Wetherald ${ }^{56}$ delineated the original, and remarkably enduring, framework for expectations of the vertical structure of human-induced temperature change. They were the first to point out stratospheric cooling accompanying the surface and tropospheric warming in response to a $\mathrm{CO}_{2}$ increase. Doubling $\mathrm{CO}_{2}$ (from 300 to $600 \mathrm{ppm}$ ) led to $\sim 2.4 \mathrm{~K}$ surface warming and $\sim 10 \mathrm{~K}$ upper stratospheric cooling, ${ }^{56}$ emphasizing the greater sensitivity of stratospheric climate. In 1970, the influential early climate assessment Study of Critical Environmental Problems ${ }^{88}$ projected that an $18 \%$ increase (by 2000) and a doubling of $\mathrm{CO}_{2}$ would cause cooling of $0.5-1$ and $2-4 \mathrm{~K}$, respectively, at $20-25 \mathrm{~km}$, albeit with considerable uncertainty. Associated surface warmings were 0.5 and $2 \mathrm{~K}$.

Although the global warming impact of LLGHGs has dominated climate research for decades, the attention of the stratospheric climate research community soon shifted from $\mathrm{CO}_{2}$ to ozone. In 1967, Manabe and Wetherald ${ }^{56}$ had already shown that stratospheric temperature was sensitive to the specification of the vertical profile of ozone. During the 1970s, concerns about emissions of CFCs from various surface sources, and of oxides of nitrogen from planned fleets of supersonic aircraft, focused on potential stratospheric ozone depletion. By 1975, a US government review ${ }^{89}$ indicated stratospheric cooling of up to $10 \mathrm{~K}$, and an unknown tropospheric response, among the possible climate impacts of halving ozone concentrations; the report stressed the considerable uncertainty in this projection.

In the late 1970 s, model investigations of the stratospheric temperature effects of ozone loss used either idealized ozone changes ${ }^{63,64}$ or ozone changes computed using chemistry schemes within 1-D or 2-D 
models. ${ }^{57-61}$ One key finding was the importance of the impact of $\mathrm{CO}_{2}$-induced temperature change on stratospheric ozone in estimating temperature trends. The decreased stratospheric temperatures due to a $\mathrm{CO}_{2}$ increase slowed stratospheric ozone destruction; the higher ozone concentrations caused heating that slightly offsets $\mathrm{CO}_{2}$-induced cooling.

Meanwhile, many GCMs extended at most into the LS, and even there had poor vertical resolution. Manabe and Wetherald ${ }^{56}$ were the first to show stratospheric cooling, and its latitude-height pattern, due to doubling $\mathrm{CO}_{2}$ in a GCM extending to $32 \mathrm{~km}$. Fels et al. ${ }^{64}$ were the first to report the $\mathrm{CO}_{2}$ cooling effect in a GCM extending throughout the stratosphere, with peak cooling of about $11 \mathrm{~K}$ at the stratopause (approximately three to six times the surface warming) for $\mathrm{CO}_{2}$ doubling. The cooling, and its latitude-height pattern, agreed well with the first 2-D model calculations of the effect of a $\mathrm{CO}_{2}$ doubling presented by Haigh and Pyle ${ }^{61}$ a year earlier.

Other modeling experiments during this period led to an improved understanding of the influence of a variety of natural and anthropogenic forcings on the vertical temperature profile. Volcanic aerosols in the stratosphere were shown to cool the surface and troposphere and warm the stratosphere ${ }^{90,91}$ (Figures 3 and 4).

LLGHGs other than $\mathrm{CO}_{2}$ were found to have similar impacts on tropospheric temperatures to $\mathrm{CO}_{2}$, but potentially distinct LS signatures, due to their lower infrared opacity. An increase in stratospheric concentrations of an LLGHG leads to both increased absorption of upwelling infrared radiation from the troposphere (warming the stratosphere) and increased emission of infrared radiation (cooling it); the net effect at a given altitude depends on the spectral properties of the gas and the upwelling infrared radiation, at the wavelength of interest. Optically thin gases such as CFCs absorb in the atmospheric window region, so led to warming near the tropical tropopause. Nitrous oxide $\left(\mathrm{N}_{2} \mathrm{O}\right)$ and CFCs led to a warming of the LS, and methane $\left(\mathrm{CH}_{4}\right)$ caused cooling throughout the stratosphere. ${ }^{92,93}$

Observational analyses of stratospheric temperature trends during this early period were scarce, particularly above the LS. Satellite observations were not yet available, and the radiosonde network had only begun 'global' observations in 1958 [but with a strong bias toward populated Northern Hemisphere land areas in developed countries that remains today (Figure 1)]. Pioneering analysis of temperature observations by Angell, ${ }^{94}$ using a 63 -station radiosonde network ${ }^{95-98}$ and rocketsonde data in the Western Hemisphere, ${ }^{99}$ showed a remarkable array of signals in a relatively short record: temperature variations associated with the equatorial stratospheric QBO, stratospheric warming following the 1963 eruption of Mt. Agung in Bali, Indonesia, recent cooling of the LS, and variations in the middle and upper stratosphere that were attributed to solar cycle changes. Thus, understanding of stratospheric temperature trends during this early period was primarily based on modeling studies, mainly projecting future trends, and retrospective analysis of the relatively short radiosonde record of LS temperatures.

\section{Assessments Focus on Forcing Mechanisms (1980s and Early 1990s)}

The 1980s and early 1990s saw increased focus on the issues of stratospheric ozone depletion and LLGHG-induced climate change, and the establishment of international mechanisms for assessing and reporting scientific understanding of these issues. The 1985 discovery of large springtime depletion of ozone over Antarctica (the 'ozone hole') ${ }^{100}$ motivated rapid growth in stratospheric research, including analyses of temperature change. The 1982 explosive eruption of the El Chichón volcano in Mexico provided an opportunity to determine the effect of the resulting sulfate aerosol on stratospheric temperatures. ${ }^{101,102}$ The 1988 report of the International Ozone Trends Panel $^{30}$ (and a relatively minor update 1 year later ${ }^{103}$ ) and the first assessment report of the Intergovernmental Panel on Climate Change (IPCC) ${ }^{104}$ assessed temperature trends and provide useful summaries of advances in the decade of the 1980s.

The ozone assessment ${ }^{30}$ (prepared in accordance with the 1987 Montreal Protocol on Substances that Deplete the Ozone Layer) devoted an entire chapter (and a large part of another chapter, on Antarctic ozone) to stratospheric temperature trends. Its summary of model simulations of 1970-1990 global mean temperature trends suggested 1.2-1.7 $\mathrm{K}_{\text {decade }}{ }^{-1}$ cooling of the upper stratosphere (at pressures less than $10 \mathrm{hPa}$ ), with smaller changes at LS altitudes. These simulations were not from GCMs but from models focused specifically on radiative and chemical processes, often for a particular latitude band.

However, a significant new development was the incorporation of observed historical stratospheric ozone changes in temperature trend calculations. Modeling studies that included Antarctic ozone loss suggested a substantial associated springtime cooling over Antarctica, ${ }^{65,105}$ a conclusion subsequently supported by observations (see Latitudinal and Seasonal 
Structure of Trends section). $\mathrm{WMO}^{30}$ provided an assessment of this mechanism, as well as estimates of global temperature change as a result of global changes in ozone that satellite measurements were beginning to reveal.

In assessing observed trends, ${ }^{27,43,106-111}$ the WMO report ${ }^{30}$ comprehensively reviewed the advantages and disadvantages of each available set of observations (radiosondes, rocketsonde, SSU, and analyses); it presented detailed comparisons of temperature time series, trends, and short-term changes (e.g., in response to El Chichón), for global and zonal means and for single locations for several levels; and it examined mechanisms controlling stratospheric temperature change, including changes in ozone, other trace gases, aerosols, solar radiation, and dynamics. The overall conclusions were that radiosonde and satellite datasets were in generally good agreement, although periods of disagreement were identified; trends based on rocketsonde data were highly uncertain; significant stratospheric cooling was limited to the Tropics and over Antarctica; and the LS warmed in response to El Chichón.

The first assessment report of the IPCC ${ }^{104}$ (created to provide scientific underpinnings to the UN Framework Convention on Climate Change) also addressed observed stratospheric temperature trends. It concentrated on 1958-1989 trends from a 63-station subset of the global network, ${ }^{95,96,107}$ which showed cooling of the 100-50-hPa LS layer over Antarctica, associated with the ozone hole. It also discussed the use of vertical temperature trend profiles (in the troposphere and stratosphere) as 'fingerprints' for detecting and identifying causes of climate change. The gross features of observed tropospheric warming and LS (pressures higher than $50 \mathrm{hPa}$ ) cooling appeared consistent with model simulations of the equilibrium response to greenhouse gas increases. However, problematic details included the inconsistency among models regarding the sign of the trend in the LS and near the tropopause, and the uncertain nature of the observations at pressures lower than $50 \mathrm{hPa}$. The ambiguity of possible causes of the stratospheric cooling (including ozone depletion, dissipation of volcanic aerosols, and increases in LLGHGs) was further complicated by recognition that the combined stratospheric cooling/tropospheric warming signal is also associated with natural climate variations (e.g., El Niño, which warms the troposphere and cools the tropical LS). ${ }^{112}$ Nevertheless, the report found 'broad agreement between the observations and equilibrium model simulations', with the main differences being related to the altitude at which warming reverses to cooling.
A second pair of major assessments by WMO and IPCC in 1995 113,114 took a more nuanced view of stratospheric temperature trends. The IPCC Second Assessment Report ${ }^{115}$ emphasized radiosonde data problems that led to spurious stratospheric cooling in the long-term record that begins in the late 1950s. By this time, the MSU data were featured as a complement to radiosonde data in the LS, ${ }^{116}$ which was described as cooling at a rate of $0.34^{\circ} \mathrm{C}$ decade $^{-1}$ since 1979 according to MSU, and at approximately the same rate since 1964 according to radiosonde data. But while radiosonde data homogeneity problems were starting to be recognized, ${ }^{6,8}$ similar issues with MSU had yet to be identified.

Improved observations of ozone trends and investigations of its effects on LS temperatures ${ }^{117,118}$ led $\mathrm{WMO}^{113}$ to conclude that 'ozone depletion is likely to have been the dominant contributor to temperature trends in the LS since 1980 and is much more important than the well-mixed greenhouse gases'. The report also noted that other potential causes of LS temperature changes (such as changes in stratospheric water vapor) were hard to quantify.

The 1991 eruption of Mount Pinatubo provided a better opportunity to test the modeled response of stratospheric temperature to volcanic aerosol than did El Chichón, because the Pinatubo eruption injected more material into the stratosphere and was better observed. Good agreement between the observed and modeled warming of the $\mathrm{LS}^{117}$ suggested the main mechanisms were reasonably well understood. Stratospheric temperature responses to the three major eruptions that had occurred since 1958 were found to be broadly similar, ${ }^{119}$ but with some differences that were subsequently ascribed largely to the phase of the QBO at the time of eruption. ${ }^{120}$

Other developments in this period included a clear demonstration that increases in tropospheric ozone could lead to a significant cooling of the $\mathrm{LS}^{121}$ and improved understanding of how increases in non$\mathrm{CO}_{2}$ greenhouse gases caused a distinct stratospheric temperature change compared to $\mathrm{CO}_{2} \cdot{ }^{122}$

\section{Ozone and Water Vapor Effects Refined (Late 1990s, Early 2000s)}

The years around the turn of the century saw considerable focus on stratospheric temperature trends. In 1995, SPARC [Stratospheric Processes And their Role in Climate, a core project of the World Climate Research Programme (WCRP)] established a Stratospheric Temperature Trend Assessment panel, chaired by V. Ramaswamy, 'to assess stratospheric temperature trends ... using and intercomparing all available 
sources of data ... including a study of the consistency of temperature trends with observed ozone trends and comparison with model predictions'. ${ }^{123}$ As the first long-running coordinated activity in this area, the panel's contributions include the temperature-trend chapter of the WMO's Scientific Assessment of Ozone Depletion ${ }^{124}$ and a review article. ${ }^{33}$ These informed a brief discussion on stratospheric temperature in the IPCC's third assessment report, ${ }^{125}$ which focused more on tropospheric and surface trends. The panel still exists, under the leadership of W. Randel and D. Thompson, as part of SPARC's theme of detection, attribution, and prediction of stratospheric change.

More refined observations of the vertical profile of ozone change were used in both $\mathrm{GCM}^{126}$ and $\mathrm{FDH}^{127}$ studies, which reinforced earlier conclusions that ozone depletion played a major role in the vertical, latitudinal, and seasonal variation of LS temperatures. However, differences among alternative LS ozone trend estimates led to differences in modeled temperature trends, particularly in the tropical LS.

Although they did not systematically compare observations and models, the SPARC panel concluded that the observed cooling in the middle and upper stratosphere exceeded expectations, given known trends in carbon dioxide and ozone. ${ }^{33}$ This conclusion was based on an underestimate of ozone-induced cooling in the upper stratosphere, as the thenavailable model calculations had not extended to this height. Around the same time, several studies reported calculations that did so, using both observed and modeled ozone changes, ${ }^{66,128-131}$ and showed greatly increased ozone-induced cooling and generally better agreement with observations.

Although work in the $1960 \mathrm{~s}^{56}$ showed the potential of changes in stratospheric water vapor to drive stratospheric temperature change, this topic was largely ignored until the late 1990s. Intriguing LS water vapor trends from balloon observations at Boulder, Colorado, ${ }^{132}$ and short satellite records ${ }^{133}$ were used in modeling studies ${ }^{33,134}$ that showed LS water vapor changes could cause a cooling with a magnitude $20-30 \%$ of that due to ozone, and exceeding that of ozone in the upper stratosphere. However, uncertainty regarding both the geographical extent (in the LS) of the observed changes and their duration (in the upper stratosphere) inhibited firm conclusions.

The SPARC panel's update of trends from SSU data through $1995^{33}$ (although Scaife et al. ${ }^{28}$ had by then reported trends through 1997) showed a continuation of the almost linear decline in nearglobal temperature in the upper stratosphere/lower mesosphere. The cooling of $2.5 \mathrm{~K} \mathrm{decade}^{-1}$ was larger in magnitude than trends observed anywhere else in the troposphere and stratosphere.

Shine et al. ${ }^{85}$ produced the first multimodel comparison with observations, exploiting available FDH and GCM results using observed ozone trends, and, for the first time, results from CCMs that calculated ozone trends. Although this use of CCMs was an important methodological advance, an added complication in assessing their temperature trends was the need also to assess the quality of the simulated ozone change, which contributed to a large spread in the CCM temperature trends. In the upper stratosphere, changes in ozone and LLGHGs (of which $\mathrm{CO}_{2}$ was the dominant contributor) appeared to explain the observed cooling, contributing approximately equally (Figure 5, left), resolving the apparent discrepancy noted earlier. ${ }^{33}$ In the mid-stratosphere a new puzzle emerged, as the modeled cooling appeared to exceed that observed. In the LS, the situation was unchanged: ozone change was the dominant contributor, but it did not clearly explain all the observed cooling, and the possibility remained that water vapor trends might make a significant contribution (Figure 5, left).

Using radiosonde data and focusing on the tropical LS, Thompson and Solomon ${ }^{135}$ reported much greater cooling than model expectations, and they argued for a missing mechanism. The integrity of the radiosonde data they used was subsequently challenged. ${ }^{136-138}$

More attention began to be focused on stratospheric temperature variations, as well as the multidecadal trend. In a GCM study, Ramaswamy et al. ${ }^{139}$ found that $1979-2003$ LS temperatures could be well simulated as a mixture of anthropogenic influences and the warming influence of the two major volcanic eruptions (El Chichón and Mt. Pinatubo) driving a step-like downward trend. ${ }^{140}$

\section{Recent Advances and New Challenges (Late 2000s)}

In the last 5 years, stratospheric temperature research has had four foci: reinvigorated analysis of radiosonde, MSU, and SSU data; coordinated modeling studies with sophisticated CCMs; documentation of stratospheric temperature variations associated with stratospheric water vapor changes and with two natural sources of climate variability, the solar cycle and ENSO; and investigation of seasonal and latitudinal patterns of temperature trends and their possible connection to changes in stratospheric circulation. The 2007 IPCC assessment ${ }^{75}$ covered radiosonde and MSU advances, but stressing the troposphere and drawing on a US national assessment. ${ }^{4}$ Growing 
recognition of linkages between ozone depletion and climate change was evidenced by dedicated chapters of both the 2006 and 2010 ozone assessments, ${ }^{52,76}$ as well as a special report coordinated by the IPCC. ${ }^{141}$

\section{Reinvigorated Analyses of Stratospheric Temperature Observations}

Stratospheric climate research benefited substantially from the controversy surrounding tropospheric temperature trends; ${ }^{1}$ increased scrutiny of radiosonde and MSU data and development of independent methods of adjusting inhomogeneous data resulted in several new LS temperature data products, $4,7,10-17,18,142$ depicted in Figures 3 and 6. As a result, there are now more estimates of LS trends than during the 20th century, and, because of their convergence over time (mainly due to the smaller cooling trends in the bias-adjusted radiosonde data compared with earlier datasets), reduced uncertainty regarding the magnitude of the global mean LS cooling (about $0.3-0.5 \mathrm{~K}$ decade $^{-1}$, Figure 6).

Motivated in part by those advances, concern grew over the quality of middle and upper stratospheric SSU data, largely because only one team had analyzed the data and most of their results were reported in assessments, without the benefit of detailed methodological description in journal articles. Stimulated by the 1988 ozone trends panel report ${ }^{30}$ and discussions of the SPARC Stratospheric Temperature

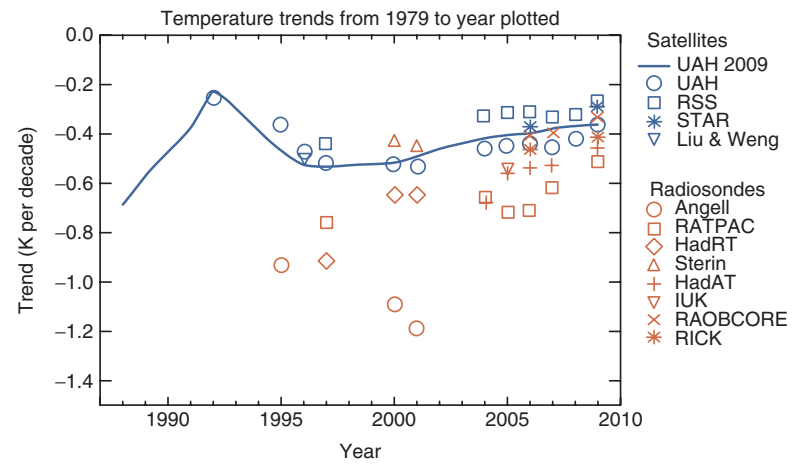

FIG URE 6 | Evolution of estimates of observed cooling trends in global mean lower stratospheric (LS) temperatures during the satellite era (since 1979), based on satellite Microwave Sounding Unit (MSU) (blue) and radiosonde (red) observations. Symbols show trends for 1979 to the year plotted, as reported in the literature, except for 1979-2009 trends which were calculated for this study. Radiosonde data are vertically weighted to correspond with the MSU LS layer (Figure 2). Blue line shows trends from the current (September 2009) version of University of Alabama in Huntsville (UAH) MSU data for each year. Differences between this line and the UAH published estimates (blue circles) illustrate the degree of change in the different versions of this dataset. See Figure 3 legend for dataset names and associated references.
Trends Assessment Panel (then cochaired by K. Shine and W. Randel), Shine et al. ${ }^{25}$ showed that increases in atmospheric $\mathrm{CO}_{2}$ significantly impacted the SSU weighting functions and derived temperature trends. Throughout most of the LS, adjustment made the derived trend significantly more negative (by typically several tenths of a degree per decade). Importantly, the adjustment at $5 \mathrm{hPa}$ brought models and observations into much better agreement. The synthetic (or ' $\mathrm{X}$ ') channels were not amenable to simple adjustment for the $\mathrm{CO}_{2}$ change. ${ }^{25}$

The SPARC panel ${ }^{21}$ applied these SSU adjustments in an update of observed stratospheric trends. The panel expressed concern over documentation of the methodology for deriving trends from SSU data, noting that 'the details of the SSU data need to be clarified in the peer-reviewed literature' and suggesting the need for 'alternative independent SSU climate data products'. Liu and Weng ${ }^{29}$ were the first to produce an alternative analysis for channels 25 and 26; Figure 4 compares the two analyses.

Like MSU and radiosondes, the SSU data show warming associated with the volcanic eruptions of $\mathrm{El}$ Chichón and Pinatubo, most marked in the two lower altitude channels, 25 and 26 (Figures 4 and 7). The upper stratospheric channel (27) indicates a cooling of about $3 \mathrm{~K}$ between 1978 and 2006, all of which occurred prior to 1996 . The two channel 26 analyses show quite different characteristics; Randel et al. ${ }^{21}$ indicate an overall cooling of around $0.5 \mathrm{~K}$, while Liu and Weng ${ }^{29}$ indicate a small warming. For channel 25 , the overall cooling is quite similar (about $1 \mathrm{~K}$ ) and the two time series are in particularly good agreement from 1989 onwards, but differ in the period following the El Chichón eruption, 1985-1989 (Figure 4).

Neither of the two SSU methodologies ${ }^{20,29}$ is sufficiently well documented to confidently identify the reasons for these differences, but some tentative conclusions can be drawn. First, the disagreement between the channel 25 analyses between 1985 and 1989 (note in particular the abrupt decrease in 1989 in the Liu and Weng data ${ }^{29}$ ) appears to be associated with a reported radiometric error (of order $0.5 \mathrm{~K}$ ) on the SSU instrument on the NOAA-9 satellite, considered in other analyses. ${ }^{20,143}$ Other shifts in the differences between the analyses seem to coincide with changes in instruments (e.g., the 1995 transition between NOAA-11 and NOAA-14), suggesting that different data merging methods may explain the differences.

The channel 26 series are more problematic, with a $1 \mathrm{~K}$ relative drift between the two analyses over the 30-year record, larger than the trend in either of them (Figure 4). One analysis ${ }^{29}$ shows no 


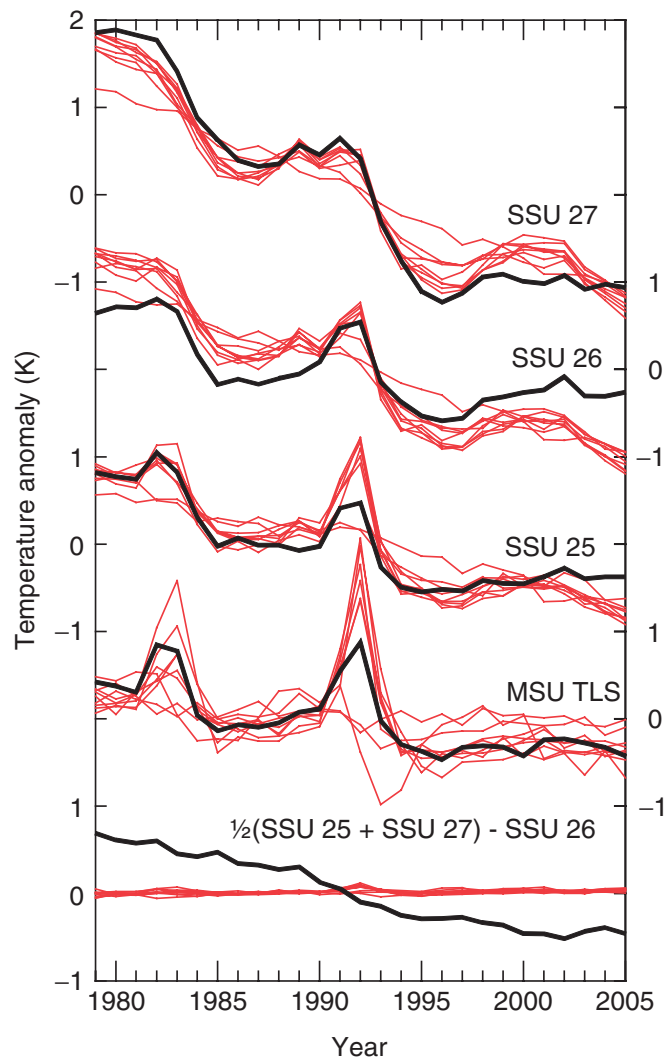

FIG URE 7 | Global mean temperature anomalies for 1979-2005 in the four vertical layers sampled by Microwave Sounding Unit lower stratosphere (MSU LS), ${ }^{15}$ Stratospheric Sounding Unit (SSU) 25, SSU 26, and SSU $27 .{ }^{21}$ The bottom trace is a combination (the average of channels 25 and 27 minus channel 26) of time series for the SSU layers from the models and as observed. See Figure 2 for the vertical layers. Observations are shown in black and simulations from eight models participating in Chemistry-Climate Model Validation Activity $(\mathrm{CCMVal})^{69}$ are shown in red. ${ }^{86}$ All anomalies are relative to the full 1979-2005 period.

net mid-stratospheric cooling, while the other ${ }^{21}$ has a significant trend. Again, some of the differences seem to be associated with satellite changes (NOAA-9 to NOAA-11 in 1989 and NOAA-11 to NOAA-14 in 1995). Another large change corresponds to a period when this channel's cell was leaking rapidly (for NOAA-7 between 1981 and $1983^{20}$ ). Liu and Weng $^{29}$ do not account for changes in observing time, due to either the change in satellite or drift in the original satellite orbit. This decision was based on earlier work relevant to the tropospheric MSU channel 2 and analysis of a period of small drift of the NOAA-15 satellite. In contrast, Nash and Forrester ${ }^{20}$ do account for this effect. ${ }^{24}$

It is unclear if this diurnal effect explains the differences in Figure 4 or if both analyses of channel 26 have problems. All the CCMVal models show a remarkable vertical consistency of temperature variations in the SSU sampling region, with simulated channel 26 anomalies differing from the average of simulated channels 25 and 27 by less than $0.1 \mathrm{~K}$ (Figure 7). The observed difference in the Randel et al. ${ }^{21}$ analysis is an order of magnitude larger and has a marked downward trend (Figure 7, bottom). While it is possible that the models are omitting other causes of temperature trends, these would have to be rather specific to the mid-stratosphere to explain the difference, which we judge unlikely.

Efforts underway to incorporate SSU data into reanalyses, ${ }^{23,50}$ in which such issues as tidal corrections will be more explicitly taken into account, may allow improved exploitation of SSU data for trend analyses in future. However, severe difficulties using SSU data in reanalyses have been identified, ${ }^{50,51}$ so reanalyses are not currently a reliable source of temperature trends in the middle to upper stratosphere.

\section{Chemistry-Climate Model Advances}

The most noteworthy modeling accomplishment of the past decade has been the development and intercomparison of many CCMs. ${ }^{69,144,145}$ Although simulating stratospheric ozone changes has been the prime purpose of these activities, ${ }^{52,76}$ high vertical resolution and relatively complete treatment of stratospheric processes make the models also applicable to stratospheric temperature studies. Moreover, because the zonal mean stratospheric temperature response to 3-D ozone changes differs from the zonal mean temperature response to zonal mean ozone changes, ${ }^{146-148} \mathrm{CCMs}$ are likely to simulate more realistic stratospheric temperature changes than GCMs with prescribed zonal mean ozone changes. Two model intercomparison projects ${ }^{69,144}$ standardized experiments from multiple models. Comparison of the modeled 1980-1999 global mean temperature trends with observations ${ }^{68,69}$ showed a large spread in model trends (about $1 \mathrm{~K}$ decade $^{-1}$ in the upper stratosphere and LS and about $0.5 \mathrm{~K} \mathrm{decade}^{-1}$ in the mid-stratosphere). The CCM temperature responses to the El Chichón and Mt. Pinatubo eruptions varied greatly among models, as also seen in comparison of GCMs. ${ }^{149,150}$ However, the multimodel mean long-term global trends were in broad agreement with observations (Figure 5, right and Figure 7).

To distinguish LLGHG and ODS contributions to stratospheric temperature trends, studies have either used CCM simulations with LLGHG or ODS changes only, ${ }^{86,151,152}$ or have applied regression analysis to simulations including both forcings. ${ }^{152-154}$ The attribution of temperature trends to ODSs differs from earlier simulations, which applied prescribed ozone changes from whatever cause. ${ }^{73,124,139,155}$ 
Identifying separate ODS- and LLGHG-attributable temperature change components results in less cooling being attributed to LLGHGs (as LLGHGinduced cooling leads to an increase in ozone through most of the stratosphere, which partly cancels the $\mathrm{CO}_{2}$-induced cooling). It also results in more cooling being attributed to ODSs than to ozone (as the observed ozone depletion is a residual of a larger ODS-induced depletion, which has been partly cancelled by $\mathrm{CO}_{2}$-induced ozone increases). ${ }^{153,154}$ The distinction between the two approaches lies in whether the warming due to LLGHG-induced ozone increases is associated with ozone forcing $73,124,139,155$ or with LLGHG changes. ${ }^{86,151,152,154}$ Consistent with earlier results, ${ }^{85}$ LLGHGs were the biggest contributor to modeled upper stratospheric cooling over this period, and ODSs were the biggest contributor to the cooling in the $\operatorname{LS}^{73,124,139,155}$ (Figure 5).

In a related approach, Stolarski et al. ${ }^{70}$ attributed their CCM stratospheric cooling to $\mathrm{CO}_{2}$, methane, and ODSs, and accounted for the impact of methane on stratospheric water vapor concentrations (via methane oxidation) and $\mathrm{HO}_{\mathrm{x}}$ levels, which lead to ozone destruction. At $1 \mathrm{hPa}$, the cooling attributed to methane between 1979 and 1998 (about $0.2 \mathrm{~K}$ decade ${ }^{-1}$ ) is more than $50 \%$ of that due to $\mathrm{CO}_{2}$; the calculations of Myhre et al. ${ }^{156}$ indicate that around half of that $\mathrm{CH}_{4}$-induced cooling is due to stratospheric water vapor increases.

Gillett et al. ${ }^{86}$ used single-forcing CCM simulations $^{151}$ to assess the causes of observed 1979-2005 stratospheric temperature changes. Comparison of observed zonal mean MSU LS trends with the simulated response to combined anthropogenic and natural forcings in the CCMVal-2 simulations indicates broad consistency, although the models show enhanced annual mean cooling over Antarctica not found in the observations, which show a relatively uniform cooling at all latitudes. ${ }^{86}$ (See Latitudinal and Seasonal Structure of Trends section for further discussion of the latitudinal variation of trends.) An attribution analysis identified a detectable influence of ODSs and natural forcings, but no detectable LLGHG contribution. ${ }^{86}$ Higher in the stratosphere, the simulated SSU 26 cooling is stronger than that observed, while the SSU 27 cooling is somewhat weaker (Figure 5, right), although, as discussed earlier, the observed SSU trends are questionable. ${ }^{69}$ The influence of natural and anthropogenic forcings could be detected in the SSU trends, but LLGHG and ODS influences could not be separately detected. ${ }^{86}$

\section{Solar, ENSO, and Water Vapor Effects}

Short-term stratospheric temperature variations influence detection and attribution of trends. An impact of solar variability on stratospheric temperature was shown decades ago. ${ }^{43,157-159}$ With longer observational datasets now available, and CCMs that explicitly simulate the effect of solar variability, there has been renewed interest; ${ }^{160}$ this has allowed better estimates of the strength of temperature variations associated with the 11 -year solar cycle, ${ }^{161}$ due to the direct effect of changing incoming solar radiation and the indirect effect of solar-cycle-induced ozone changes. ${ }^{162}$ Randel et al. ${ }^{21}$ using regression analysis on SSU and MSU data, found the average peakto-peak amplitude due to the solar cycle increased from about $0.5 \mathrm{~K}$ in the tropical LS to over $1 \mathrm{~K}$ in the upper stratosphere. A similar method applied to ECMWF 40-Year Re-analysis (ERA) data ${ }^{163}$ found a more marked vertical structure with a stratopause peak reaching $2 \mathrm{~K}$, a mid-stratospheric minimum, and a secondary LS peak exceeding $1 \mathrm{~K}$. Austin et al. ${ }^{164}$ compared a range of CCM simulations, finding a response with a peak of around $0.8 \mathrm{~K}$ at the tropical stratopause, a relative minimum in the midstratosphere, and a secondary peak (not always statistically significant) in the tropical LS. However, the ability of CCMs to simulate the stratospheric temperature response to solar variability is heavily dependent on the specification of the wavelength dependence of that variability, which has recently been questioned. ${ }^{84}$

On shorter time scales, stratospheric temperature variability associated with ENSO has been better quantified through modeling and observational studies. Stratospheric cooling (above tropospheric warming) in the tropics during El Niños had been documented in the $1990 \mathrm{~s}^{112,165}$ and more recently, an Arctic wintertime response, modulated by the QBO, has also been identified in observations ${ }^{166-169}$ and models ${ }^{170-173}$ in association with changes in the strength of the polar vortex.

Given the sensitivity of temperature trends to stratospheric water vapor ${ }^{85,127}$ (Figure 5, left), recent investigations of water vapor trends have a bearing on our understanding of temperature change. There have been updated analyses of trends in stratospheric water vapor ${ }^{78,81}$ and particular attention to a marked and sudden decrease in stratospheric water vapor after 2001, and its relationship to tropical tropopause temperatures, ${ }^{52,77-79}$ but no dedicated analyses of the influence of these changes on stratospheric temperature.

\section{Latitudinal and Seasonal Structure of Trends}

This review has focused on global and annual mean trends, and their height variation, but observed LS temperature trends have exhibited notable spatial and seasonal structure, particularly in high latitudes 
FIG URE 8 | Global map (left) and latitudinal variation (right) of Microwave Sounding Unit lower stratospheric (MSU LS) temperature trends during 1979-2010, based on Remote Sensing Systems (RSS) version 3.3 data. Error bars on zonal mean trends are 2- $\sigma$ estimates of internal data uncertainties. ${ }^{176}$ (Figure courtesy of Carl Mears, RSS)
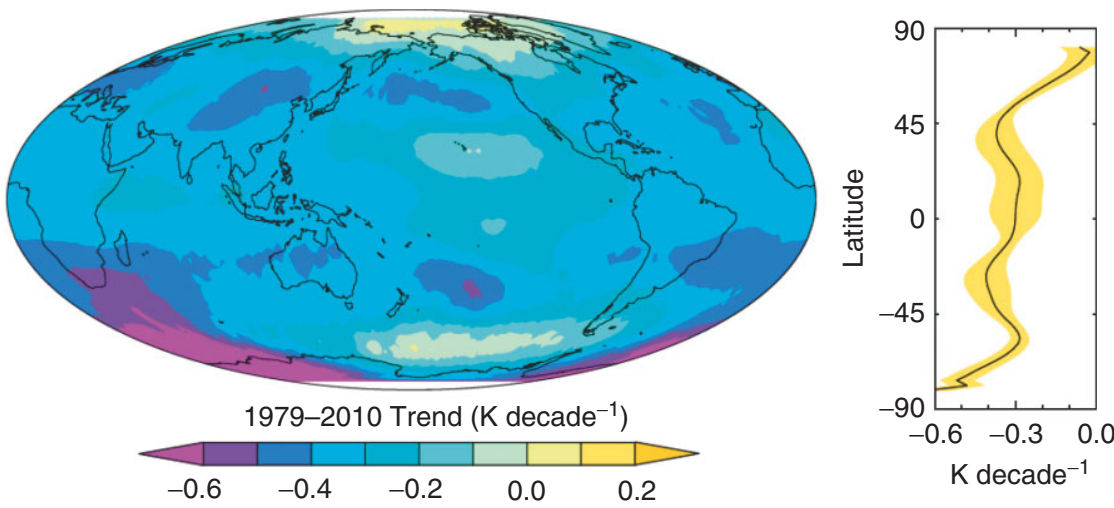

(Figures 8 and 9), which may be explained by several mechanisms. First, model studies indicate that even a homogeneous change in LLGHG concentrations (and in the absence of atmospheric circulation changes) can lead to a significant meridional variation in temperature change. ${ }^{64,134}$ Second, some changes in forcing agents have considerable spatial and seasonal structure (the springtime Antarctic ozone hole is an obvious example), causing local departures of temperature trends from their global and annual mean. ${ }^{127,130}$ Third, changes in dynamical heat transport (e.g., because of changes in the strength of the winter polar vortex in the LS or in the Brewer-Dobson overturning circulation of the global stratosphere) can also lead to spatial and seasonal variations in temperature trends ${ }^{65,66,174}$ sometimes reinforcing radiatively driven temperature trends. ${ }^{175}$ Dynamical changes are not believed to be capable of generating appreciable globally averaged temperature changes at any given pressure level, because conservation of mass dictates that enhanced ascent at one latitude (and associated adiabatic cooling) must be balanced by enhanced descent at another (with associated adiabatic warming). Detailed modeling studies are generally required to infer if observed variations in temperature trends have a radiative or dynamical cause, or some combination of the two.

In the annual average, MSU LS data indicate that zonal mean 1979-2010 cooling trends have been largest in the Antarctic, associated with the maximum in stratospheric ozone depletion there (Figure 8). Note that this latitudinal structure was not apparent in 1979-2005 trends, ${ }^{21,86}$ due in part to the anomalously warm conditions in the Antarctic LS during 2003-2006, which were followed by anomalously cold conditions during 2007-2010. Interpreting these latitudinal trend variations in MSU data is complicated by the broad MSU LS weighting function and the high tropical tropopause: MSU LS samples more of the upper troposphere in the Tropics than at higher latitudes (Figure 2).
Radiosonde data at $50 \mathrm{hPa}$ (a stratospheric level at all latitudes) and MSU LS data for 1979-2009 show cooling of the tropical LS in all months, but it is largest between June and January (Figure 9). Fu et al. ${ }^{177}$ suggest these seasonal differences in the tropics are related to changes in stratospheric circulation, but Free $^{179}$ notes that the seasonal variation in tropical $50-\mathrm{hPa}$ trends found in multiple radiosonde datasets is mainly due to temperature changes in the mid-1990s.

The seasonal trend differences appear to be larger in the polar regions, with greatest cooling in the spring, ${ }^{135}$ but trend uncertainties are larger here (Figure 9), due to the greater interannual variability in higher latitudes, poor sampling by radiosondes, and disparities among the available datasets. $\mathrm{Hu}$ and $\mathrm{Fu}^{180}$ focus on a 1979-2006 warming observed in part of the Southern Hemisphere high-latitude LS in early spring. They attribute it to increased dynamical heating, which they reproduce in a simulation with prescribed SST changes; similarly, they find that early winter warming in the Northern Hemisphere is reproduced in simulations with prescribed observed SSTs, associated with a strengthened Brewer-Dobson circulation. ${ }^{180}$

Given the observational uncertainty, conflicting reported seasonal and latitudinal patterns of trends, and the complex evolution of LS temperature, further study is needed to clarify the nature of the trends and the possible role of stratospheric circulation changes.

\section{SYNTHESIS AND CURRENT CHALLENGES}

Since the advent in the 1960s of simple models showing the effect of changes in greenhouse gas concentrations on stratospheric climate, and accelerated by the increased attention to ozone depletion in the 1970s and 1980s, research has identified potential causes of past and future stratospheric temperature change and showed evidence of temperature trends in available observations over the past three to five 

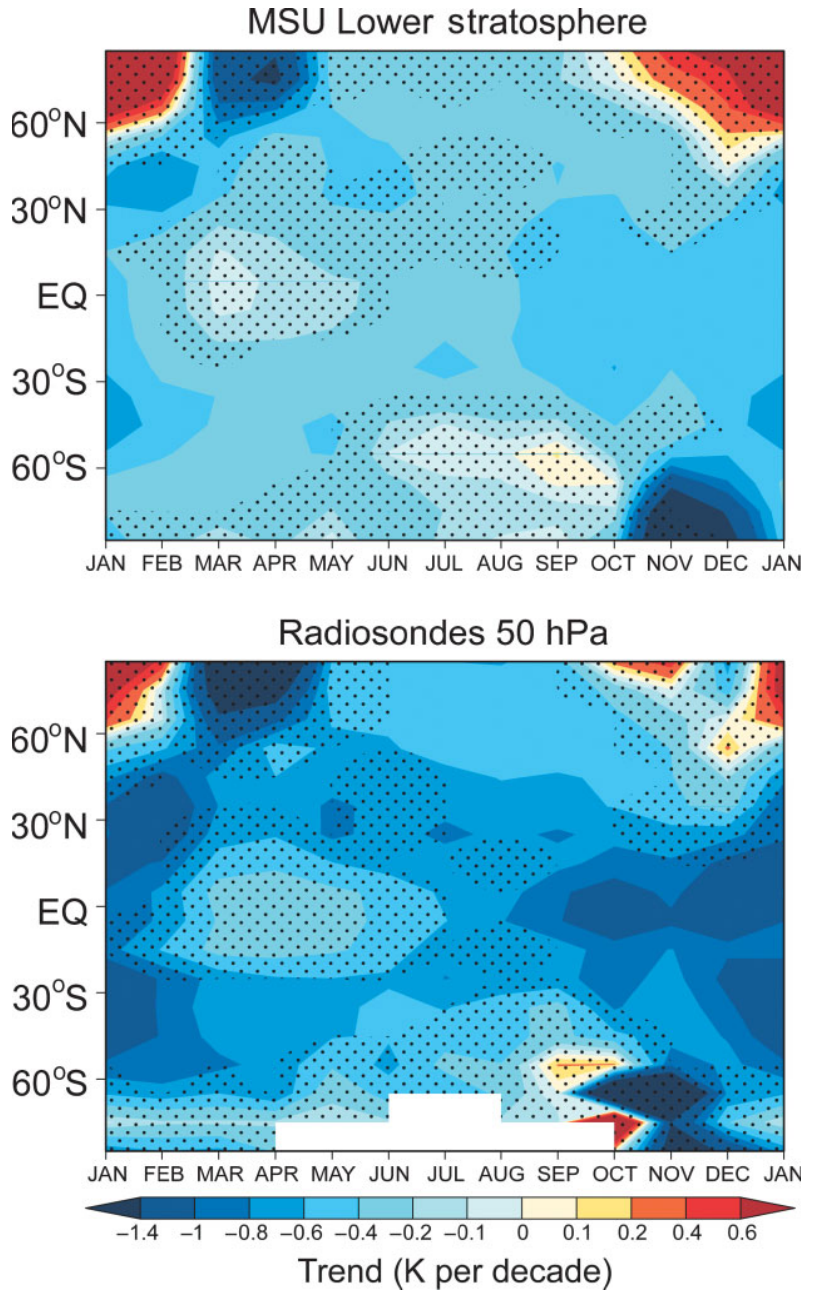

FIG URE 9 | Lower stratospheric (LS) temperature trends during 1979-2009 as a function of latitude and month from Microwave Sounding Unit (MSU) LS observations (top) and radiosonde 50-hPa observations (bottom). Each panel shows a composite of trend estimates from different datasets, including the Remote Sensing Systems (RSS), University of Alabama in Huntsville (UAH), and NOAA Center for Satellite Applications and Research (STAR) Microwave Sounding Unit (MSU) datasets and the Hadley Centre Atmospheric Temperatures (HadAT), RAdiosonde OBservation COrrection using REanalyses (RAOBCORE), Radiosonde Atmospheric Temperature Products for Assessing Climate (RATPAC), and Radiosonde Innovation Composite Homogenization (RICH) radiosonde datasets. Areas without stippling have trends that are statistically significant at the 95\% confidence level in all datasets in the composite and all are of the same sign. (Updated and modified from Fu et al., ${ }^{177}$ Forster et al. ${ }^{178}$ and Free. ${ }^{179}$ Figure courtesy of Melissa Free, NOAA Air Resources Lab)

decades. But while tropospheric temperature trend research ${ }^{1}$ focused on the rate of change, stratospheric investigations have concentrated on the causes, with greater reliance on model simulations and less attention to understanding observations (particularly in the middle and upper stratosphere).
Analyses of LS observations from radiosondes and AMSU/MSU all show cooling of about $0.4 \mathrm{~K}$ decade $^{-1}$ over the past three decades (Figures 3, 5, 6, 8 , and 9), and their differences suggest an uncertainty of about $\pm 0.2 \mathrm{~K} \mathrm{decade}{ }^{-1}$; however, the number of analyses is small and actual uncertainties may be larger (Figure 6). Recognition and adjustment of spurious signals in radiosonde data have yielded smaller cooling trends than in unadjusted radiosonde data, but greater cooling than MSU, and there is lingering concern as to whether these problems have been (or ever can be) fully resolved.

Models of several sorts indicate that stratospheric cooling trends have been driven largely by changes in greenhouse gases (mostly $\mathrm{CO}_{2}$ ), ozone, and perhaps water vapor (Figure 5). In the LS, ozone depletion has been the dominant driver, and models reproduce the evolution of global mean temperature reasonably well, including the temperature spikes $(\sim 1 \mathrm{~K})$ following major volcanic eruptions and the observed lack of significant global and annual mean trend since the mid-1990s (Figure 7).

A relatively recent development has been the attribution of temperature changes to particular causes, including their indirect effects (e.g., a $\mathrm{CO}_{2}$ increase causing cooling that causes ozone increase and a partially compensating warming). The highly uncertain water vapor trends introduce considerable uncertainty into comparisons of simulated and observed stratospheric temperature trends. There is little hope of improving observational estimates of past trends in water vapor due to the paucity of highquality observations in the upper troposphere and stratosphere.

Lessons learned about data problems at lower altitudes have heightened concerns over the robustness of estimated trends at higher altitudes, where, until quite recently, the community has largely relied on a single, poorly documented analysis of SSU data. Because there are no complementary global observations, characterizing structural uncertainty is more difficult than for the LS. The very recent release of a second SSU analysis has allowed a limited first comparison with the older methodology (Figure 4) and with model simulations (Figure 7), raising questions about all SSU datasets. Thus, observed temperature trends in the upper and middle stratosphere are considerably more uncertain than in the LS. Nevertheless, current analyses indicate global average temperature decreased from the late 1970s to the mid-1990s and has since stayed relatively constant.

The lack of temperature trend throughout the stratosphere for the past 15 years has not been the subject of detailed analysis, although stable LS 
temperatures since 1995 are also reproduced in simulations including observed variations in ODSs, LLGHGs, volcanic aerosol, and solar irradiance (Figure 7). Presumably, the combined and compensating effects of these changes explain the lack of global and annual mean trend, but quantitative attribution studies of this period, during which the stratosphere has been unaffected by volcanic aerosols, have yet to be made.

Stratospheric temperature variability associated with natural climate variations was recognized in early studies and has been more extensively analyzed over time. Major transient stratospheric temperature increases can result from volcanic eruptions (Figures 3, 4, and 7), at least into the middle stratosphere, but simulated warming spans a wide range of magnitudes. Solar variations become increasingly significant in the upper stratosphere. The role of ENSO in the stratosphere, in both the tropics and extratropics, and connections between stratospheric temperature and circulation changes are emerging topics in the overall understanding of stratosphere/troposphere linkages in interannual climate variability.

Reliable simulations of stratospheric temperature change are needed for accurate projections of stratospheric ozone and radiative forcing. Understanding of the nature and causes of stratospheric temperature changes has increased markedly in the past two decades, due to international climate and ozone assessments and intercomparison exercises as well as individual scientific papers. However, that work has revealed areas of considerable uncertainty in analysis of observations and in knowledge of the mechanisms that drive temperature changes. While overall the simulated evolution of middle and upper stratospheric temperatures in the latest coupled CCM simulations agrees reasonably well with observations, unless we can increase confidence in temperature trends derived from satellites, the extent of that agreement is difficult to assess (Figure 7). In the LS, the availability of several alternative observational datasets enhances confidence in the robustness of current understanding.

\section{ACKNOWLEDGMENTS}

We thank Tom Peterson (NOAA National Climatic Data Center), Mark Ringer (UK Met Office), Thierry Leblanc (Jet Propulsion Laboratory), Sean Healy (ECMWF), Melissa Free and Jim Angell (NOAA Air Resources Laboratory), Cheng-Zhi Zou (NOAA Center for Satellite Applications and Research), Craig Long (NOAA Climate Prediction Center), Bill Randel (NCAR), Norm McFarlane (Canadian Centre for Climate Modelling and Analysis) and WIREs: Climate Change reviewers and editors Michael Hulme and Neville Nichols for valuable comments during the preparation of this manuscript. We are also grateful for the assistance of Carl Mears (RSS), Andreas Jonsson (University of Toronto), Katharine Willett (UK Met Office Hadley Centre), Melissa Free, the NOAA NCDC Graphics Team (Glenn Hyatt, Deb Misch, Deborah Riddle, and Sara Veasey), and Leo Shine in preparing some of the figures, and Mara Sprain (STG, Inc., NOAA NCDC) in organizing the references.

\section{REFERENCES}

1. Thorne PW, Lanzante JR, Peterson TC, Seidel DJ, Shine KP. Tropospheric temperature trends: history of an ongoing controversy. WIREs: Clim Change 2010, 2:66-88. doi:10.1002/wcc.80.

2. Spencer RW, Christy JR. Precise monitoring of global temperature trends from satellites. Science 1990, 247:1558-1562.

3. National Research Council. Reconciling Observations of Global Temperature Change. Washington, DC: National Academy Press; 2000, 85.

4. Karl TR, Hassol SJ, Miller CD, Murray WL, eds. Temperature Trends in the Lower Atmosphere: Steps for Understanding and Reconciling Differences. Washington, DC: U.S. Climate Change Science Program and Subcommittee on Global Change Research; 2006. Available at: http://www.climatescience.gov/Library/ sap/sap1-1/finalreport/default.htm. (Accessed June 6, 2011)

5. Thorne PW, Parker DE, Christy JR, Mears CA. Uncertainties in climate trends-lessons from upper-air temperature records. Bull Am Meteorol Soc 2005, 86:1437-1442.

6. Gaffen DJ. Temporal inhomogeneities in radiosonde temperature records. J Geophys Res 1994, 99: 3667-3676. doi:10.1029/93JD03179.

7. Lanzante JR, Klein SA, Seidel DJ. Temporal homogenization of monthly radiosonde temperature data. Part I: Methodology. J Clim 2003, 16:224-240.

8. Parker D, Cox D. Towards a consistent global climatological rawinsonde data-base. Int J Climatol 1995, 15:473-496. 
9. Zou C-Z, Wang W. Stability of the MSU-derived atmospheric temperature trend. J Atmos Ocean Technol 2010, 27:1960-1971.

10. Thorne PW, Parker DE, Tett SFB, Jones PD, McCarthy $\mathrm{M}$, Coleman H, Brohan P. Revisiting radiosonde upper air temperatures from 1958 to 2002. J Geophys Res 2005, 110:D18105. doi:10.1029/2004JD005753.

11. Free M, Seidel DJ, Angell JK, Lanzante JR, Durre I, Peterson TC. Radiosonde Atmospheric Temperature Products for Assessing Climate (RATPAC): a new data set of large-area anomaly time series. J Geophys Res 2005, 110:D22101. doi:10.1029/2005JD006169.

12. Sherwood SC, Meyer CL, Allen RJ, Titchner HA. Robust tropospheric warming revealed by iteratively homogenised radiosonde data. J Clim 2008, 21: 5336-5352.

13. Haimberger L. Homogenization of radiosonde temperature time series using innovation statistics. J Clim 2007, 20:1377-1403.

14. Haimberger L, Tavolato C, Sperka S. Toward elimination of the warm bias in historic radiosonde temperature records-some new results from a comprehensive intercomparison of upper-air data. J Clim 2008, 21:4587-4606.

15. Mears CA, Wentz FJ. Construction of the Remote Sensing Systems V3.2 atmospheric temperature records from the MSU and AMSU microwave sounders. J Atmos Ocean Tech 2009, 26:1040-1056.

16. Christy J, Spencer R, Norris W, Braswell W, Parker D. Error estimates of version 5.0 of MSU-AMSU bulk atmospheric temperatures. J Atmos Ocean Tech 2003, 20:613-629.

17. Zou C-Z, Gao M, Goldberg MD. Error structure and atmospheric temperature trends in observations from the microwave sounding unit. J Clim 2009, 22:1661-1681.

18. Zou C-Z, Goldberg MD, Cheng Z, Grody NC, Sullivan JT, Cao C, Tarpley D. Recalibration of microwave sounding unit for climate studies using simultaneous nadir overpasses. J Geophys Res 2006, 111:D19114. doi:10.1029/2005JD006798.

19. Peterson TC, Baringer MO, eds. State of the climate in 2008. Bull Am Meteorol Soc 2009, 90:S1-S196.

20. Nash J, Forrester GF. Long-term monitoring of stratospheric temperature trends using radiance measurements obtained by the TIROS-N series of NOAA spacecraft. Adv Space Res 1986, 6:37-44.

21. Randel WJ, Shine KP, Austin J, Barnett J, Claud C, Gillett NP, Keckhut P, Langematz U, Lin R, Long C, et al. An update of observed stratospheric temperature trends. J Geophys Res 2009, 114:D02107. doi:10.1029/2008JD010421.

22. Nash J. Extension of explicit radiance observations by the stratospheric sounding unit into the lower stratosphere and lower mesosphere. Q JR Meteorl Soc 1988, 114:1153-1171.
23. Kobayashi S, Matricardi M, Dee D, Uppala S. Toward a consistent reanalysis of the upper stratosphere based on radiance measurements from SSU and AMSU-A. Q J R Meteorol Soc 2009, 135:2086-2099.

24. Brownscombe JL, Nash J, Vaughan G, Rogers CF. Solar tides in the middle atmosphere. I. Description of satellite observations and comparison with theoretical calculations at equinox. Q J R Meteorol Soc 1985, 111:677-689.

25. Shine KP, Barnett JJ, Randel WJ. Temperature trends derived from stratospheric sounding unit radiances: the effect of increasing $\mathrm{CO}_{2}$ on the weighting function. Geophys Res Lett 2008, 35:L02710. doi:10.1029/2007GL032218.

26. Mo T. A study of the NOAA-15 AMSU-A brightness temperatures from 1998 through 2007. J Geophys Res 2009, 114:D11110. doi:10.1029/2008JD011267.

27. Nash J, Edge PR. Temperature changes in the stratosphere and lower mesosphere 1979-1988 inferred from TOVS radiance observations. Adv Space Res 1989, 9:333-341.

28. Scaife AA, Austin J, Butchart N, Pawson S, Keil M, Nash J, James IN. Interannual variability of the stratosphere diagnosed from UKMO TOVS analyses. Q J R Meteorol Soc 2000, 126:2585-2604.

29. Liu Q, Weng F. Recent stratospheric temperature trends observed from satellite measurements SOLA 2009, 5:53-56. doi:10.2151/sola.2009-014.

30. World Meteorological Organization. Report of the International Ozone Trends Panel: 1988. Geneva: WMO; 1988 [Global Ozone Research and Monitoring Project Report No. 18].

31. Dunkerton TJ, Delisi DP, Baldwin MP. Middle atmosphere cooling trend in historical rocketsonde data. Geophys Res Lett 1998, 25:3371-3374.

32. Keckhut P, Schmidlin FJ, Hauchecorne A, Chanin ML. Stratospheric and ozone-depleting substances to mesospheric cooling trend estimates from US rocketsondes at low latitude stations $\left(8^{\circ} \mathrm{S}-34^{\circ} \mathrm{N}\right)$, taking into account instrumental changes and natural variability. J Atmos Sol-Terr Phys 1999, 61:447-459.

33. Ramaswamy V, Chanin ML, Angell J, Barnett J, Gaffen D, Gelman M, Keckhut P, Koshelkov Y, Labitzke K, Lin JJR, et al. Stratospheric temperature trends: observations and model simulations. Rev Geophys 2001, 39:71-122.

34. Keckhut P, McDermid S, Swart D, McGee T, GodinBeekmann S, Adriani A, Barnes J, Baray JL, Bencherif $\mathrm{H}$, Claude $\mathrm{H}$, et al. Review of ozone and temperature lidar validations performed within the framework of the network for the detection of stratospheric change. J Environ Mon 2004, 6:721-733.

35. Keckhut P, Randel WJ, Claud C, Leblanc T, Steinbrecht W, Funatsu BN, Bencherif H, McDermid IS, Hauchecorne A, Long C, et al. An evaluation of 
uncertainties in monitoring middle atmosphere temperatures with the ground-based lidar network in support of space observations. J Atmos Sol-Terr Phys 2011, 73:627-642. doi:10.1016/j.jastp.2011.01.003.

36. Kursinski ER, Hajj G, Schofield J, Linfield R, Hardy K. Observing Earth's atmosphere with radio occultation measurements using the global positioning system. J Geophys Res 1997, 102:23429-23465.

37. Marquardt C, von Engeln A, Andres Y, Sancho F. Inter-instrument and structural uncertainty in radio occultation data: comparing COSMIC and GRAS data and retrievals. In: 13th Conference on Integrated Observing and Assimilation Systems for Atmosphere, Oceans, and Land Surface (IOAS-AOLS), 10-15 January 2009; Phoenix, USA. Boston: American Meteorological Society; 2009, Paper 7A.6.

38. von Engeln A. A first test of climate monitoring with radio occultation instruments: comparing two processing centers. Geophys Res Lett 2006, 33:L22705. doi:10.1029/2006GL027767.

39. Ho S-P, Kirchengast G, Leroy S, Wickert J, Mannucci AJ, Steiner AK, Hunt D, Schreiner W, Sokolovskiy F, Ao CO, et al. Estimating the uncertainty of using GPS radio occultation data for climate monitoring: intercomparison of CHAMP refractivity climate records 2002-2006 from different data centers. J Geophys Res 2009, 114:D23107. doi:10.1029/2009JD011969.

40. Ringer MA, Healy SB. Monitoring twenty-first century climate using GPS radio occultation bending angles. Geophys Res Lett 2008, 35:L05708. doi:10. 1029/2007GL032462.

41. Steiner AKG, Kirchengast G, Lackner BC, Pirscher B, Borsche M, Foelsche U. Atmospheric temperature change detection with GPS radio occultation 1995 to 2008. Geophys Res Lett 2009, 36:L18702. doi:10. 1029/2009GL039777.

42. Gelman ME, Nagatani RM. Objective analysis of height and temperature at the 5-, 2-, and $0.4 \mathrm{mb}$ levels using meteorological rocketsonde and satellite radiation data. Adv Space Res 1977, 17:117-122.

43. Naujokat B. Long-term variations in the stratosphere of the northern hemisphere during the last two sunspot cycles. J Geophys Res 1981, 86:9811-9816.

44. Labitzke K, Naujokat B. On the variability and on trends of the temperature in the middle stratosphere. Beitr Phys Atmos 1983, 56:495-507.

45. Thorne PW, Vose RS. Reanalyses suitable for characterizing long-term trends: are they really achievable? Bull Am Meteorol Soc 2010, 91:353-361.

46. Thorne PW. Arctic tropospheric warming amplification? Nature 2008, 455:E1-E2. doi:10.1038/ nature 07256 .

47. Bitz CM, Fu Q. Arctic warming aloft is data set dependent. Nature 2008, 455:E3-E4. doi:10.1038/ nature 07258 .
48. Grant AN, Bronnimann S, Haimberger L. Recent Arctic warming vertical structure contested. Nature 2008, 455:E2-E3. doi:10/1038/nature07257.

49. Sakamoto M, Christy JR. The influences of TOVS radiance assimilation on temperature and moisture tendencies in JRA-25 and ERA-40. J Atmos Ocean Tech 2009, 26:1435-1455.

50. Saha S, Moorthi S, Pan HL, Wu X, Wang J, Nadiga S, Tripp P, Kistler R, Woollen J, Behringer D, et al. The NCEP climate forecast system reanalysis. Bull Am Meteorol Soc 2010, 91:1015-1057.

51. Onogi K, Tsutsui J, Koide H, Sakamoto M, Kobayashi S, Hatsushika H, Matsumoto T, Yamazaki N, Kamahori H, Takahashi K, et al. The JRA-25 reanalysis. J Meteor Soc Japan 2007, 85:369-432.

52. World Meteorological Organization. Scientific Assessment of Ozone Depletion: 2010. Geneva: WMO; 2011, 516 [Global Ozone Research and Monitoring Project Report No. 52].

53. Xu J, Powell AM. Ensemble spread and its implication for the evaluation of temperature trends from multiple radiosonde and reanalyses products. Geophys Res Lett 2010, 37:L17704. doi:10.1029/2010GL044300.

54. Dee DP, Källén E, Simmons AJ, Haimberger L. Comments on "Reanalyses suitable for characterizing longterm trends”. Bull Am Meteorol Soc 2010, 92:65-70. doi:10.1175/2010BAMS3070.1.

55. Manabe S, Strickler RF. Thermal equilibrium of the atmosphere with a convective adjustment. J Atmos Sci 1964, 21:361-385.

56. Manabe S, Wetherald R. Thermal equilibrium of the atmosphere with a given distribution of relative humidity. J Atmos Sci 1967, 24:241-259.

57. Ramanathan V, Callis LB, Boughner RE. Sensitivity of surface-temperature and atmospheric-temperature to perturbations in stratospheric concentration of ozone and nitrogen-dioxide. J Atmos Sci 1976, 33: 1092-1112.

58. Luther FM, Wuebbles DJ, Chang JS. Temperature feedback in a stratospheric model. J Geophys Res 1977, 82:4935-4942.

59. Boughner RE. The effect of increased carbon dioxide concentrations on stratospheric ozone. J Geophys Res 1978, 83:1326-1332.

60. Groves KS, Mattingly SR, Tuck AF. Increased atmospheric carbon dioxide and stratospheric ozone. Nature 1978, 273:711-715.

61. Haigh JD, Pyle JA. A two-dimensional calculation including atmospheric carbon-dioxide and stratospheric ozone. Nature 1979, 279:222-224.

62. Brasseur G, Hitchmann MH. Stratospheric response to trace gas perturbations: changes in ozone and temperature distributions. Science 1988, 240:634-637. 
63. Ramanathan V, Dickinson R. The role of stratospheric ozone in the zonal and seasonal radiative energy balance of the Earth-troposphere system. J Atmos Sci 1979, 36:1084-1104.

64. Fels SB, Mahlman JD, Schwarzkopf MD, Sinclair RW. Stratospheric sensitivity to perturbations in ozone and carbon-dioxide-radiative and dynamical response. J Atmos Sci 1980, 37:2265-2297.

65. Kiehl JT, Boville BA. The radiative-dynamical response of a stratospheric-tropospheric general circulation model to changes in ozone. JAtmos Sci 1988, 45:1798-1817.

66. Rosier SM, Shine KP. The effect of two decades of ozone change on stratospheric temperatures as indicated by a general circulation model. Geophys Res Lett 2000, 27:2617-2620.

67. Meehl GA, Stocker TF, Collins WD, Friedlingstein P, Gaye AT, Gregory JM, Kitoh A, Knutti R, Murphy JM, Noda A, et al. Global climate projections. In: Solomon S, Qin D, Manning M, Chen Z, Marquis M, Averyt KB, Tignor M, Miller HL, eds. Climate Change 2007: The Physical Science Basis. Cambridge and New York: Cambridge University Press; 2007, 747-845.

68. Austin J, Wilson RJ, Akiyoshi H, Bekki S, Butchart N, Claud C, Fomichev VI, Forster P, Garcia RR, Gillett NP, et al. Coupled chemistry climate model simulations of stratospheric temperatures and their trends for the recent past. Geophys Res Lett 2009, 36:L13809. doi:10.1029/2009GL038462.

69. SPARC Chemistry-Climate Model Validation Activity Group. Eyring V, Shepherd TG, Waugh DW, eds. SPARC Report on the Evaluation of ChemistryClimate Models. 2010. [SPARC Report No. 5, WCRP132, WMO/TD-No. 1526] Available at: http://www. atmosp.physics.utoronto.ca/SPARC/ccmval_final/ index.php. (Accessed June 6, 2011).

70. Stolarski RS, Douglass AR, Newman PA, Pawson $S$, Schoerberl MR. Relative contribution of greenhouse gases contribution of greenhouse gases and ozone depleting substances to temperature trends in the stratosphere. J Clim 2010, 23:28-42.

71. Karpechko AY, Gillett NP, Marshall GJ, Screen JA. Climate impacts of the southern annular mode simulated by the CMIP3 models. J Clim 2009, 22: 3751-3768.

72. Sausen R, Santer BD. Use of changes in tropopause height to detect human influences on climate. Meteorol Z 2003, 12:131-136.

73. Santer BD, Wehner MF, Wigley TML, Sausen R, Meehl GA, Taylor KE, Ammann C, Arblaster J, Washington WM, Boyle JS, et al. Contributions of anthropogenic and natural forcing to recent tropopause height changes. Science 2003, 301:479-483.

74. Seidel DJ, Randel WJ. Variability and trends in the global tropopause estimated from radiosonde data. J Geophys Res 2006, 111:D21101. doi:10.1029/ 2006JD007363.
75. Solomon S, Qin D, Manning M, Chen Z, Marquis M, Averyt KB, Tignor M, Miller HL, eds. Climate Change 2007: The Physical Science Basis. Cambridge and New York: Cambridge University Press; 2007, 996.

76. World Meteorological Organization. Scientific Assessment of Ozone Depletion: 2006. Geneva: WMO; 2007, 572 [Global Ozone Research and Monitoring Project Report No. 50].

77. Randel WJ, Wu F, Vömel H, Nedoluha GE, Forster P. Decreases in stratospheric water vapor after 2001: links to changes in the tropical tropopause and the Brewer-Dobson circulation. J Geophys Res 2006, 111:D12312. doi:10.1029/2005JD006744.

78. Scherer M, Vömel H, Fueglistaler S, Oltmans SJ, Staehelin J. Trends and variability of midlatitude stratospheric water vapour deduced from the re-evaluated Boulder balloon series and HALOE. Atmos Chem Phys 2008, 8:1391-1402.

79. Solomon S, Rosenlof KH, Portmann RW, Daniel JS, Davis SM, Sanford TJ, Plattner G-K. Contributions of stratospheric water vapor to decadal changes in the rate of global warming. Science 2010, 327: 1219-1223.

80. Fujiwara M, Vömel H, Hasebe F, Shiotani M, Iwasaki S, Nishi N, Shibata T, Shimizu K, Nishimoto E, Valverde Canossa JM, et al. Seasonal to decadal variations of water vapor in the tropical lower stratosphere observed with balloon-borne cryogenic frost point hygrometers. J Geophys Res 2010, 115:D18304. doi:10.1029/2010JD014179.

81. Hurst DF, Oltmans SJ, Vömel H, Rosenlof KH, Davis SM, Ray EA, Hall EG, Jordan AF. Stratospheric water vapor trends over Boulder, Colorado: analysis of the 30 year Boulder record. J Geophys Res 2011, 116:D02306. doi:10.1029/2010JD015065.

82. Lean J, Rottman G, Harder J, Kopp G. SORCE contributions to new understanding of global change. Sol Phys 2005, 230:27-53.

83. Harder JW, Fontenla JM, Pilewskie P, Richard EC, Woods TN. Trends in solar spectral irradiance variability in the visible and infrared. Geophys Res Lett 2009, 36:L07801. doi:07810.01029/ 02008 GL036797.

84. Haigh JD, Winning AR, Toumi R, Harder JW. An influence of solar spectral variations on radiative forcing of climate. Nature 2010, 467:696-699.

85. Shine KP, Bourqui MS, Forster PMD, Hare SHE, Langematz U, Braesicke P, Grewe V, Schnadt C, Smith CA, Haigh JD, et al. A comparison of model-predicted trends in stratospheric temperatures. Q J R Meteorl Soc 2003, 129:1565-1588. doi:10.1256/qJ02.186.

86. Gillett NP, Akiyoshi H, Bekki S, Eyring V, Garcia R, McLinden CA, Karpechko AY, Plummer DA, Rozanov E, Scinocca J, et al. Attribution of observed changes in stratospheric ozone and temperature. Atmos Chem Phys 2011, 11:599-609. doi:10.5194/acp-11-599-2011. 
87. Forster PM, Fomichev VI, Rozanov E, Cagnazzo C, Jonsson AI, Langematz U, Fomin B, Iacono MJ, Mayer B, Mlawer E, et al. Evaluation of radiation scheme performance within chemistry-climate models. J Geophys Res 2011, 116:D10302. doi:10.1029/ 2010JD015361.

88. SCEP (Study of Critical Environmental Problems). In: Matthews WH, ed. Man's Impact on the Global Environment: Assessment and Recommendations for Action. Cambridge, MA: MIT Press; 1970, 319.

89. Federal Task Force on Inadvertent Modification of the Stratosphere. Fluorocarbons and the Environment. Washington, DC: Council on Environmental Quality, Federal Council for Science and Technology; 1975, 109.

90. Pollack JB, Toon OB, Sagan C, Summers A, Baldwin B, Vancamp W. Volcanic explosions and climatic change-theoretical assessment. J Geophys Res 1976, 81:1071-1083.

91. Hansen JE, Wang WC, Lacis AA. Mount Agung eruption provides test of a global climatic perturbation. Science 1978, 199:1065-1068.

92. Dickinson RE, Liu SC, Donahue TM. Effect of chlorofluoromethane infrared radiation on zonal atmospheric temperatures. J Atmos Sci 1978, 35: 2142-2152.

93. Donner L, Ramanathan V. Methane and nitrousoxide-their effects on the terrestrial climate. J Atmos Sci 1980, 37:119-124.

94. Seidel DJ, Robock A, Angell J, Hicks B, Labitzke K, Lanzante J, Logan J, Mahlman J, Ramaswamy V, Randel B, et al. Jim Angell's contributions to meteorology: report from a symposium honoring him on his 80 th birthday. Bull Am Meteorol Soc 2005, 86:404-410. doi:10.1175/BAMS-86-3-403.

95. Angell JK, Korshover J. Estimate of the global change in tropospheric temperature between 1958 and 1973. Mon Wea Rev 1975, 103:1007-1012.

96. Angell JK, Korshover J. Estimate of global change in temperature, surface to $100 \mathrm{mb}$, between 1958 and 1975. Mon Wea Rev 1977, 105:375-385.

97. Angell JK, Korshover J. Comparison of stratospheric trends in temperature, ozone and water vapor in north temperate latitudes. J Appl Meteorol 1978, 17: 1396-1401.

98. Angell JK, Korshover J. Estimate of global temperature variations in the 100-30 mb layer between 1958 and 1977. Mon Wea Rev 1978, 106:1423-1432.

99. Angell JK, Korshover J. Recent rocketsonde-derived temperature variations in the Western Hemisphere. J Atmos Sci 1978, 35:1758-1764.

100. Farman JC, Gardiner BG, Shanklin JD. Large losses of total ozone in Antarctica reveal seasonal $\mathrm{ClOx} / \mathrm{NOx}$ interaction. Nature 1985, 315:207.

101. Pitari G, Visconti G, Matarese A. Stratospheric heating due to El Chichón volcanic eruption: preliminary results using a 3D model. Il Nuovo Cimento C 1985 , 8:680-697. doi:10.1007/BF02558001.

102. Jäger H, Carnuth W. The decay of the El Chichón stratospheric perturbation, observed by lidar at northern midlatitudes. Geophys Res Lett 1987, 14:696-699. doi:10.1029/GL014i007p00696.

103. World Meteorological Organization. Scientific Assessment of Stratospheric Ozone: 1989. Geneva: WMO; 1990 [Global Ozone Research and Monitoring Project Report No. 20].

104. Houghton JT, Jenkins GJ, Ephraums JJ, eds. Climate Change: The IPCC Scientific Assessment. Cambridge and New York: Cambridge University Press; 1990, 881.

105. Shine KP. On the modeled thermal response of the Antarctic stratosphere to a depletion of ozone. Geophys Res Lett 1986, 13:1331-1334.

106. Oort AH. Global Atmospheric Circulation Statistics, 1958-1973. Washington, DC: U.S. Government Printing Office; 1983, 180 [NOAA Professional Paper 14].

107. Angell JK. Variations and trends in tropospheric and stratospheric global temperatures, 1958-87. J Clim 1988, 1:1296-1313.

108. Parker DE. The influence of the Southern Oscillation and volcanic eruptions on temperature in the tropical troposphere. Int J Clim 1985, 5:273-282.

109. Labitzke K, Brasseur G, Naujokat B, de Rudder A. Long-term temperature trends in the stratosphere: possible influence of anthropogenic gases. Geophys Res Lett 1986, 13:52-55.

110. Labitzke K, Naujokat B, Angell JK. Long-term temperature trends in the middle stratosphere of the Northern Hemisphere. Adv Space Res 1986, 6:7-16.

111. Nash J, Brownscombe JL. Validation of the stratospheric sounding unit. Adv Space Res 1983, 2:59-62.

112. Reid GC. Seasonal and interannual temperature variations in the tropical stratosphere. J Geophys Res 1994, 99:18923-18932. doi:10.1029/94JD01830.

113. World Meteorological Organization. Scientific Assessment of Ozone Depletion: 1994. Geneva: WMO; 1995 [Global Ozone Research and Monitoring Project Report No. 37].

114. Houghton JT, Meira Filho LG, Callander BA, Harris $\mathrm{N}$, Kattenberg A, Maskell K, eds. Climate Change 1995. The Science of Climate Change. Cambridge and New York: Cambridge University Press; 1996, 572.

115. Nicholls N, Gruza GV, Jouzel J, Karl TR, Ogallo LA, Parker DE. Observed climate variability and change. In: Houghton JT, Meira Filho LG, Callander BA, Harris N, Kattenberg A, Maskell K, eds. Climate Change 1995. The Science of Climate Change. Cambridge and New York: Cambridge University Press; 1996, 133-192.

116. Spencer R, Christy J. Precision lower stratospheric temperature monitoring with the MSU: technique, 
validation, and results 1979-1991. J Clim 1993, 6:1194-1204.

117. Hansen J, Lacis A, Ruedy R, Sato M, Wilson H. How sensitive is the world's climate? Res Exp 1993, 9:142-158.

118. McCormack JP, Hood LL. Relationship between ozone and temperature trends in the lower stratosphere-latitude and seasonal dependences. Geophys Res Lett 1994, 21:1615-1618.

119. Angell JK. Comparison of stratospheric warming following Agung, El Chichón and Pinatubo volcanic eruptions. Geophys Res Lett 1993, 20:715-718.

120. Angell JK. Stratospheric warming due to Agung, El Chichón, and Pinatubo taking into account the quasi-biennial oscillation. J Geophys Res 1997, 102: 9479-9485.

121. Ramaswamy V, Bowen MM. Effect of changes in radiatively active species upon the lower stratospheric temperatures. J Geophys Res 1994, 99:18909-18921.

122. Wang WC, Dudek MP, Liang XZ, Kiehl JT. Inadequacy of effective $\mathrm{CO}_{2}$ as a proxy in simulating the greenhouse-effect of other radiatively active gases. Nature 1991, 350:573-577.

123. Chanin ML. The SPARC programme. Phys Chem Earth 1995, 20:21-32.

124. World Meteorological Organization. Scientific Assessment of Ozone Depletion: 1998. Geneva: WMO; 1999 [Global Ozone Research and Monitoring Project Report No. 44].

125. Houghton JT, Ding Y, Griggs DJ, Noguer M, van der Linden PJ, Dai X, Maskell K, Johnson CA, eds. Climate Change 2001: The Scientific Basis. Cambridge and New York: Cambridge University Press; 2001, 881.

126. Ramaswamy V, Schwarzkopf MD, Randel WJ. Fingerprint of ozone depletion in the spatial and temporal pattern of recent lower-stratospheric cooling. Nature 1996, 382:616-618.

127. Forster PMD, Shine KP. Radiative forcing and temperature trends from stratospheric ozone changes. J Geophys Res 1997, 102:10841-10855.

128. Langematz U. An estimate of the of the impact of observed ozone losses on stratospheric temperature. Geophys Res Lett 2000, 27:2077-2080.

129. Austin J. A three-dimensional coupled chemistryclimate model simulation of past stratospheric trends. J Atmos Sci 2002, 59:218-232.

130. Ramaswamy V, Schwarzkopf MD. Effects of ozone and well-mixed gases on annual-mean stratospheric temperature trends. Geophys Res Lett 2002, 29:2064. doi:10.1029/2002GL015141.

131. Langematz U, Kunze M, Krüger K, Labitzke K, Roff GL. Thermal and dynamical changes of the stratosphere since 1979 and their link to ozone and $\mathrm{CO}_{2}$ changes. J Geophys Res 2003, 108:4027. doi:10.1029/ 2002JD002069.
132. Oltmans SJ, Hofmann DJ. Increase in lower-stratospheric water-vapor at a mid-latitude northernhemisphere site from 1981 to 1994. Nature 1995, 374: 146-149.

133. Nedoluha GE, Bevilacqua RM, Gomez RM, Siskind DE, Hicks BD, Russell JM, Connor BJ. Increases in middle atmospheric water vapor as observed by the Halogen Occultation Experiment and the groundbased water vapor millimeter-wave spectrometer from 1991 to 1997. J Geophys Res 1998, 103:3531-3543.

134. Forster PMD, Shine KP. Stratospheric water vapour changes as a possible contributor to observed stratospheric cooling. Geophys Res Lett 1999, 26:3309-3312.

135. Thompson DWJ, Solomon S. Recent stratospheric climate trends as evidenced in radiosonde data: global structure and tropospheric linkages. J Clim 2005, 18:4785-4795.

136. Randel WJ, Wu F. Biases in stratospheric and tropospheric temperature trends derived from historical radiosonde data. J Clim 2006, 19:2094-2104.

137. Free M, Seidel DJ. Comment on "Biases in stratospheric and tropospheric temperature trends derived from historical radiosonde data" by Randel and Wu (2006). J Clim 2007, 20:3704-3709. doi:10.1175/ JCLI4210.1.

138. Randel WJ, Wu F. Reply to comment of Free and Seidel. J Clim 2007, 20:3710-3711.

139. Ramaswamy V, Schwarzkopf MD, Randel WJ, Santer BD, Soden BJ, Stenchikov GL. Anthropogenic and natural influences in the evolution of lower stratospheric cooling. Science 2006, 311:1138-1141.

140. Seidel DJ, Lanzante JR. An assessment of three alternatives to linear trends for characterizing global atmospheric temperature changes. J Geophys Res 2004, 109:D14108. doi:10.1029/2003JD004414.

141. Metz B, Kuijpers L, Solomon S, Andersen SO, Davidson O, Pons J, de Jager D, Kestin T, Manning M, Meyer L, eds. Safeguarding the Ozone Layer and the Global Climate System: Issues Related to Hydrofluorocarbons and Perfluorocarbons. Cambridge: Cambridge University Press; 2005, 478.

142. Lanzante JR, Klein SA, Seidel DJ. Temporal homogenization of monthly radiosonde temperature data. Part II: Trends, sensitivities, and MSU comparison. J Clim 2003, 16:241-262.

143. Brindley HE, Geer AJ, Harries JE. Climate variability and trends in SSU radiances: a comparison of model predictions and satellite observations in the middle atmosphere. J Clim 1999, 12:3197-3219.

144. Eyring V, Butchart N, Waugh DW, Akiyoshi H, Austin J, Bekki S, Bodeker GE, Boville BA, Bruhl C, Chipperfield MP, et al. Assessment of temperature, trace species, and ozone in chemistry-climate model simulations of the recent past. J Geophys Res 2006, 111:D22308. doi:10.1029/2006JD007327. 
145. Garcia RR, Marsh DR, Kinnison DE, Boville BA, Sassi F. Simulation of secular trends in the middle atmosphere, 1950-2003. J Geophys Res 2007, 112: D09301. doi:10.1029/2006JD007485.

146. Crook JA, Gillett NP, Keeley SPE. Sensitivity of Southern Hemisphere climate to zonal asymmetry in ozone. Geophys Res Lett 2008, 35:L07806. doi:10.1029/2007GL032698.

147. Gillett NP, Scinocca JF, Plummer DA, Reader MC. Sensitivity of climate to dynamically-consistent zonal asymmetries in ozone. Geophys Res Lett 2009, 36:L10809. doi:10.1029/2009GL037246.

148. Waugh DW, Oman L, Newman PA, Stolarski RS, Pawson S, Nielsen JE, Perlwitz J. Effect of zonal asymmetries in stratospheric ozone on simulated Southern Hemisphere climate trends. Geophys Res Lett 2009, 36:L18701. doi:10.1029/2009GL040419.

149. Lanzante JR, Free M. Comparison of radiosonde and GCM vertical temperature trend profiles: effects of dataset choice and data homogenization. J Clim 2008, 21:5417-5435. doi:10.1175/2008JCLI2287.1.

150. Free M, Lanzante JR. Effect of volcanic eruptions on the vertical temperature profile in radiosonde data and climate models. I Clim 2009, 22:2925-2939. doi:10.1175/2008JCLI2562.

151. Eyring V, Cionni I, Bodeker GE, Charlton-Perez AJ, Kinnison DE, Scinocca JF, Waugh DW, Akiyoshi H, Bekki S, Chipperfield MP, et al. Multi-model assessment of stratospheric ozone return dates and ozone recovery in CCMVal-2 models. Atmos Chem Phys 2010, 10:9451-9472.

152. Plummer DA, Scinocca JF, Shepherd TG, Reader MC, Jonsson AI. Quantifying the contributions to stratospheric ozone changes from ozone depleting substances and greenhouse gases. Atmos Chem Phys 2010, 10:8803-8820. doi:10.5194/acp-10-8803-2010.

153. Shepherd TG, Jonsson AI. On the attribution of stratospheric ozone and temperature changes to changes in ozone depleting substances and well-mixed greenhouse gases. Atmos Chem Phys 2008, 8:1435-1444.

154. Jonsson AI, Fomichev VI, Shepherd TG. The effect of nonlinearity in $\mathrm{CO}_{2}$ heating rates on the attribution of stratospheric ozone and temperature changes. Atmos Chem Phys 2009, 9:8447-8452.

155. Cordero E, Forster PMD. Stratospheric variability and trends in models used for the IPCC AR4. Atmos Chem and Phys 2006, 6:5369-5380.

156. Myhre G, Nilsen JS, Gulstad L, Shine KP, Rognerud $\mathrm{B}$, Isaksen ISA. Radiative forcing due to stratospheric water vapour from $\mathrm{CH} 4$ oxidation. Geophys Res Lett 2007, 34:L01807. doi:10.1029/2006GL027472.

157. Fritz S, Angell JK. Temperature and wind variation in the tropical stratosphere and lower mesosphere during a sunspot cycle. J Geophys Res 1976, 81:1051-1055.
158. Zerefos CS, Crutzen PJ. Stratospheric thickness variations over the northern hemisphere and their possible relation to solar activity. J Geophys Res 1975 , 80:5041-5043.

159. Callis LB, Nealy JE. Solar UV variability and its effect on stratospheric thermal structure and trace constituents. Geophys Res Lett 1978, 5:249-252.

160. Gray LJ, Beer J, Geller M, Haigh JD, Lockwood M, Matthes K, Cubasch U, Fleitmann D, Harrison G, Hood L, et al. Solar influences on climate. Rev Geophys 2010, 48:RG4001. doi:10.1029/2009RG 000282.

161. Labitzke K, Austin J, Butchart N, Knight J, Takahashi M, Nakamoto M, Nagashima T, Haigh J, Williams V. The global signal of the 11-year solar cycle in the stratosphere: observations and models. J Atmos Sol-Terr Phys 2002, 64:203-210.

162. McCormack JP, Hood LL. Apparent solar cycle variations of upper stratospheric ozone and temperature: latitude and seasonal dependences. J Geophys Res 1996, 101:20933-20944.

163. Frame THA, Gray LJ. The 11-year solar cycle in ERA-40 data: an update to 2008. J Clim 2010, 23:2213-2222.

164. Austin J, Tourpali K, Rozanov E, Akiyoshi H, Bekki S, Bodeker G, Brühl C, Butchart N, Chipperfield M, Deushi M, et al. Coupled chemistry climate model simulations of the solar cycle in ozone and temperature. J Geophys Res 2008, 113:D11306. doi:10.1029/2007JD009391.

165. Lau KM, Ho CH, Kang IS. Anomalous atmospheric hydrologic processes associated with ENSO: mechanisms of hydrologic cycle-radiation interaction. J Clim 1998, 11:800-815.

166. Crooks SA, Gray LJ. Characterization of the 11-year solar signal using a multiple regression analysis of the ERA-40 dataset. J Clim 2005, 18:996-1015.

167. Camp CD, Tung K-K. Stratospheric polar warming by ENSO in winter: a statistical study. Geophys Res Lett 2007, 34:L04809. doi:10.1029/2006GL028521.

168. Garfinkel CI, Hartmann DL. Effects of the El-Niño Southern Oscillation and the Quasi-Biennial Oscillation on polar temperatures in the stratosphere. J Geophys Res 2007, 112:D19112. doi:10.1029/ 2007JD008481.

169. Free M, Seidel DJ. Observed El Niño-Southern Oscillation temperature signal in the stratosphere. J Geophys Res 2009, 114:D23108. doi:10.1029/2009JD012420.

170. Garcia-Herrera R, Calvo N, Garcia RR, Giorgetta MA. Propagation of ENSO temperature signals into the middle atmosphere: a comparison of two general circulation models and ERA-40 reanalysis data. J Geophys Res 2006, 111:D06101. doi:10.1029/ 2005JD006061.

171. Sassi F, Kinnison D, Boville BA, Garcia RR, Roble R. Effect of El Niño-Southern Oscillation on the 
dynamical, thermal, and chemical structure of the middle atmosphere. J Geophys Res 2004, 109:D17108. doi:10.1029/2003JD004434.

172. Manzini E, Giorgetta MA, Esch M, Kornblueh L, Roeckner E. The influence of sea surface temperatures on the northern winter stratosphere: ensemble simulations with the MAECHAM5 model. J Clim 2006, 19: 3863-3881.

173. Ineson S, Scaife AA. The role of the stratosphere in the European climate response to El Niño. Nat Geosci 2009, 2:32-36.

174. Gillett NP, Thompson DWJ. Simulation of recent Southern Hemisphere climate change. Science 2003, 302:273-275.

175. Garcia RR, Randel WJ. Acceleration of the BrewerDobson circulation due to increases in greenhouse gases. J Atmos Sci 2008, 65:2731-2739. doi:10.1175/ 2008JAS2712.1.

176. Mears CA, Wentz FJ, Thorne P, Bernie D. Assessing uncertainty in estimates of atmospheric temperature changes from MSU and AMSU using a MonteCarlo estimation technique. J Geophys Res 2011, 116:D08112. doi:10.1029/2010JD014954.

177. Fu Q, Solomon S, Lin P. On the seasonal dependence of tropical lower-stratospheric temperature trends. Atmos Chem Phys 2010, 10:2643-2653. doi:10.5194/ acp-10-2643-2010.

178. Forster PM, Thompson DWJ (Coordinating Lead Authors), Baldwin MP, Chipperfield MP, Dameris M, Haigh JD, Karoly DJ, Kushner PJ, Randel WJ, Rosenlof KH, et al. Stratospheric changes and climate. In: World Meteorological Organization: Scientific Assessment of Ozone Depletion: 2010. Geneva: WMO; 2011, 4.1-4.60 [Global Ozone Research and Monitoring Project Report No. 52].

179. Free M. The seasonal structure of temperature trends in the tropical lower stratosphere. J Clim 2011, 24:859-866. doi:10.1175/2010JCLI3841.1.

180. Hu Y, Fu Q. Stratospheric warming in Southern Hemisphere high latitudes since 1979. Atmos Chem Phys 2009, 9:4329-4340. doi:10.5194/acp-9-4329-2009. 